\section{Assessment of seasonal and spatial variation of surface water quality, identification of factors associated with water quality variability, and the modeling of critical nonpoint source pollution areas in an agricultural watershed}

\author{
D.D. Poudel, T. Lee, R. Srinivasan, K. Abbaspour, and C.Y. Jeong
}

\begin{abstract}
Surface water quality impairment in agricultural watersheds is a major environmental concern in the United States. To assess seasonal and spatial variability of surface water quality and identify factors associated with surface water quality variability, we monitored surface water quality at seven locations in Bayou Plaquemine Brule Watershed in Louisiana twice monthly from March of 2002 to February of 2008 and performed multivariate analyses of the dataset. Using the Soil and Water Assessment Tool (SWAT) model, we identified critical areas of nonpoint source pollution in the watershed. While temperature, turbidity, dissolved oxygen (DO), conductivity and $\mathrm{pH}$ were determined in the field using YSI Sonde (YSI Incorporated, Yellow Springs, Ohio), surface water samples were analyzed for total nitrogen (TN), total phosphorus (TP), nitrate/nitrite- $\mathrm{N}\left(\mathrm{NO}_{3} / \mathrm{NO}_{2}-\mathrm{N}\right)$, soluble reactive phosphate (SRP), total suspended solids (TSS), and five-day biological oxygen demand $\left(\mathrm{BOD}_{5}\right)$ in laboratory. The monthly water quality sampling included a regular sampling and an after-rain-event sampling. Average DO for the summer months, March through November, was $4.91 \pm 0.08 \mathrm{mg} \mathrm{L}^{-1}$ $(4.91 \pm 0.08 \mathrm{ppm})$, while average DO for the winter months, December through February, was $8.32 \pm 0.12 \mathrm{mg} \mathrm{L}^{-1}(8.32 \pm 0.12 \mathrm{ppm})$. Dissolved oxygen was negatively correlated with $\mathrm{TN}(r=-0.22, p \leq 0.001)$, SRP $(r=-0.17, p \leq 0.001)$, TP $(r=-0.17, p \leq 0.001), \mathrm{BOD}_{5}$ $(r=-0.25, p \leq 0.001)$, and surface water temperature $(r=-0.70, p \leq 0.001)$. Turbidity was strongly correlated with TSS $(r=0.59, p \leq 0.001)$, suggesting that most turbidity in the water body comes from suspended solids. Similarly $\mathrm{BOD}_{5}$ was significantly positively correlated with TN $(r=0.43, p \leq 0.001), \mathrm{NO}_{3} / \mathrm{NO}_{2}-\mathrm{N}(r=0.26, p \leq 0.001), \mathrm{TP}(r=0.25, p \leq 0.001)$, and SRP $(r=0.18, p \leq 0.001)$. Results of factor analyses showed sediment, phosphorus $(\mathrm{P})$, nitrogen $(\mathrm{N})$, surface water temperature, dissolved solids, and acidity/alkalinity as the most important factors associated with surface water quality variability in this watershed. Although relatively higher concentrations of sediments, TP, and TN were observed in the upper reaches of the watershed based on water quality monitoring, the SWAT simulation results showed the critical nonpoint source pollution areas of sediment, $\mathrm{P}$, and $\mathrm{N}$ in the lower reaches of the watershed. Lower reaches of the watershed have mainly rice and crawfish production, while the upper reaches include primarily sugarcane, pasturelands, and soybean production. Information on seasonal variability of surface water quality, factors associated with surface water quality variability, and the critical areas for nonpoint source pollution will be valuable inputs for developing a watershed management plan for effective nonpoint source pollution control in an agricultural watershed.
\end{abstract}

Kew words: agricultural watershed-factor analyses—nonpoint source pollution-SWAT model — total suspended solids — water quality monitoring
Agriculture is the leading cause of nonpoint source pollution and water quality impairment in United States (USGAO 1990; Hamilton and Miller 2002; James et al. 2007). Erosion from agricultural lands, excess amount of fertilizer and manure applications, higher animal stocking densities, channel erosion, and constructional activities are responsible for nonpoint source pollution in the waterways (Carpenter 1998; Poudel et al. 2010). In addition, residential areas are also an important source of nonpoint source pollution (Poudel and Jeong 2009). Decomposition of organic materials in the waterways also results in the addition of nitrogen $(\mathrm{N})$, phosphorus $(\mathrm{P})$, and other minerals to water bodies. Low dissolved oxygen (DO) in a water body is often the result of elevated oxygen-demanding substances, elevated total suspended solids (TSS), and algal bloom. Nonpoint source pollution from dissolved substances such as chloride $(\mathrm{Cl})$, sulfate $\left(\mathrm{SO}_{4}\right)$, and carbonate $\left(\mathrm{CO}_{3}\right)$ also contaminate water bodies due to application of fertilizers, limestone, rock weathering, pesticides, or from urban runoff.

Seasonal and spatial variability in surface water quality has been reported by several researchers (Clarke et al. 2002; FranceLanord et al. 2003; Mankin et al. 2003; Nagano et al. 2003; El-Kaddah and Carey 2004). The seasonal pattern of surface water quality characteristics, especially nutrients and suspended solids, corresponds to the seasonality of agricultural production. Jaynes et al. (2004) reported a higher level of nitrate $\left(\mathrm{NO}_{3}\right)$ concentration from late fall to midsummer and lower level of $\mathrm{NO}_{3}$ concentration in late summer in Walnut Creek Watershed, Iowa, United States. Randall et al. (2003) found that $62 \%$ of the annual drainage and $69 \%$ of the annual $\mathrm{NO}_{3}$ loss

Durga D. Poudel is professor and assistant director of the School of Geosciences, University of Louisiana at Lafayette, Louisiana. Taesoo Lee is assistant professor in the Department of Geography, Chonnam National University, South Korea. Raghavan Srinivasan is professor of ecosystem science and management and biological agricultural engineering at Texas A\&M University, College Station, Texas. Karim Abbaspour is a senior scientist at the Eawag: Swiss Federal Institute of Aquatic Science and Technology, Duebendorf, Switzerland. Changyoon Jeong is a research scientist at the School of Plant, Environmental, and Soil Sciences, AgCenter, Louisiana State University, Baton Rouge, Louisiana. 
occurred in April, May, and June in their field experiment site in Minnesota, United States. Similarly, Eyles et al. (2003) found higher levels of Campylobacter in summer when there was a heavy recreational use of the Taieri River in New Zealand. Spatial variability of soils, geology, natural features, land management practices, and chemical use for agricultural production (Hamilton and Miller 2002; Gelbrecht et al. 2005) results in the spatial variability of surface water quality across an agricultural watershed.

Surface water quality parameters' values change daily, monthly, seasonally, or annually because of differences in agricultural activities, land use types, degradation of streamside vegetation, seasons, and rain events in an agricultural watershed (Bennett et al. 2004; Sridhar et al. 2004; Poudel 2006), and the water quality parameters exhibit a high level of multicollinearity (Poudel and Simon 2008). The parameters' values also change due to in-stream biogeochemical processes, atmospheric deposition, and hydrological changes. Because of the high level of multicollinearity among the water quality parameters, it is possible to explain the variability in surface water quality just by a few groups of water quality parameters. Researchers have evaluated water quality data using multivariate techniques, such as the principal component, cluster, and factor analyses, and have identified factors that explain the variability in water quality (Mazlum et al. 1999; Wang et. al. 2006; Praus 2007; Alkarkhi et al. 2008). Mazlum et al. (1999) reported six principal components (PC) explaining more than $70 \%$ of the total variance of their water quality data. They found DO, electrical conductivity, temperature, and five-day biological oxygen demand $\left(\mathrm{BOD}_{5}\right)$ associated with $\mathrm{PC1}$; suspended solids and methyl orange alkalinity with $\mathrm{PC} 2$; $\mathrm{Cl}$ and ammonia nitrogen $\left(\mathrm{NH}_{3}-\right.$ N) with $\mathrm{PC} 3 ; \mathrm{NO}_{3}$ with $\mathrm{PC} 4 ; \mathrm{pH}$ with PC5; and alkalinity with PC6. Similarly, Alkarkhi et. al. (2008) identified two factors explaining $82 \%$ of the total variance in their water quality study and reported the association of turbidity, temperature, biological oxygen demand (BOD), and phosphate $\left(\mathrm{PO}_{4}\right)$ with factor 1 and $\mathrm{pH}, \mathrm{DO}$, and conductivity with factor 2 . Prioritization of the conservation measures to be implemented for nonpoint source pollution control can be done effectively by considering the principal components or the factors associated with water quality variability.

Researchers have relied on water quality modeling using computer models, such as the Agricultural Nonpoint Source Pollution Model, the Environmental Policy Integrated Climate Model, the Areal Nonpoint Source Watershed Environment Response Simulation Model, and the Soil and Water Assessment Tool (SWAT) (Bouraoui and Dillaha 2000; Forster et al. 2000; Rostamian et al. 2008), for the identification of critical areas where elevated amounts of nonpoint source pollution occur in an agricultural watershed. The computer models have been successfully used in modeling flows and sediment yields and in predicting annual stream discharges of watersheds (Jha et al. 2004; Rostamian et al. 2008). They have also simulated land use change scenarios, groundwater discharge and recharge, and nutrient loads in streams and rivers and identified critical areas for nonpoint source pollution (Srinivasan et al. 2005; Busteed et al. 2009; Radcliffe et al. 2009). An integration of water quality monitoring and modeling has been suggested to better understand surface water quality and to make appropriate and effective decisions for nonpoint source pollution control (Davenport et al. 2008).

The specific objectives of this study were to (1) assess seasonal variability of surface water quality, (2) understand the relationships between surface water quality parameters, (3) identify factors associated surface water quality variability, and (4) identify critical areas of nonpoint source pollutants in a coastal agricultural watershed. Assessment of seasonal and spatial variability of surface water quality helps in the identification and design of season-specific and location-specific management strategies for nonpoint source pollution control. Since agricultural activities are seasonal, specific attention should be given in minimizing nonpoint source pollution when major agricultural activities such as planting, fertilizer application, and crop harvesting occur. Similarly, as land use types and cropping systems vary across the landscape of an agricultural watershed, site-specific nonpoint source pollution control measures are required. Understanding relationships between several water quality parameters helps in managing and monitoring surface water quality of a water body more effectively so that it can meet the standards of its designated uses; it also helps in lowering the number of water quality parameters for monitoring. Identifying factors associated with water quality variability will help in prioritizing the implementation of conservation measures which will reduce costs, labor, and time required for the improvement of impaired water bodies. Identification of critical areas for nonpoint pollution sources in an agricultural watershed helps landowners and watershed management agencies focus their nonpoint source pollution mitigation activities in these critical areas and minimizes the cost of controlling nonpoint source pollution.

\section{Materials and Methods}

Study Area. This study was conducted in the 147,846 ha $(365,335$ ac) Bayou Plaquemine Brule Watershed in southwestern Louisiana, United States, which has been included in Louisiana's 303(d) list of impaired water bodies since 1998 (LDEQ 1999). Elevation for the watershed ranges from the mean sea level near the watershed outlet to $21 \mathrm{~m}$ (70 $\mathrm{ft}$ ) above mean sea level in the northernmost part. Crowley (Fine, smectitic, thermic Typic Albaqualfs) and Midland (Fine, smectitic, thermic Chromic Vertic Epiaqualfs) constitute the two major soil series in the watershed, while Patoutville (Fine-silty, mixed, superactive, hyperthermic Aeric Epiaqualfs) and Jeanerette (Fine-silty, mixed, superactive, hyperthermic Typic Argiaquolls) are dominant soil series in loessal terraces of the Bayou Plaquemine Brule Watershed. Acadia (Fine, smectitic, thermic Aeric Epiaqualfs) series soils dominate forest-prairie transitional zones that are found along the Bayou Plaquemine Brule and its tributaries. Major tributaries of Bayou Plaquemine Brule include Hazelwood Gully, Cole Gully, Long Point Gully, Bayou Wikoff, Bayou Blanc, and North Coulee Trief. Annual average rainfall from 1980 to 2008 in the watershed was $1,498 \mathrm{~mm}$ (59 in), and relatively more rainfall was received during the months of June through October. Agriculture accounts for $89 \%$ of land use, and remaining land use types include urban $(3.5 \%)$, forest $(3.8 \%)$, wetland $(2.9 \%)$, and others (0.8\%) (LDEQ 1999). Major agricultural activities in the watershed include rice (Oryza sativa), sugarcane (Saccharum officinarum L.), soybean (Glycine max), and crawfish production. Pastureland that supports much livestock production, primarily beef cattle, is also common in the watershed. 
Water Quality Monitoring. Seven water quality monitoring sites were identified (figure 1) after an interdisciplinary team that included a hydrologist, an engineer, a soil and water conservationist, an environmental scientist, a soil scientist, and a geographic information systems specialist made several trips to the watershed. The monitoring sites were determined based on water discharge characteristics, representation of tributaries, consideration of upstream and downstream locations of the main channel, and accessibility to collect grab samples. Four of the seven sites were in the Bayou Plaquemine Brule main channel, while three sites represented its tributaries. We monitored surface water quality at these sites from March of 2002 to February of 2008. Water quality sampling was done by grab method. Two sampling events, one background sample and one after-rainevent sample, occurred every month. The monthly two sampling events occurred even for months which lacked rain events, and the samples were considered background samples. Water sampling consisted of lowering a plastic bucket from the bridge and collecting a composite sample at $80 \%$ depth from the surface of the water. Each composite sample filled $2 \mathrm{~L}$ (0.53 gal) glass or plastic bottles. In order to avoid cross contamination, the sampling bucket lowered from the bridge was rinsed thoroughly with the first collection of water sample from the site, and then it was lowered again for actual sample collection. Similarly, each sampling bottle for a site was rinsed first with the water from the site then was filled with the water sample. Water samples from the bucket were transferred to a bottle by dipping the bottle into the water. The water sample bottles were immediately capped, labeled, and put in an ice chest with ice packs. Water samples were transported to the laboratory immediately after the completion of water sampling. Laboratory determinations of water quality samples were done from October of 2002 to February of 2008 and were analyzed for $\mathrm{BOD}_{5}$, TSS, soluble reactive phosphate $(\mathrm{SRP})$, total $\mathrm{P}(\mathrm{TP})$, nitrate and nitrite- $\mathrm{N}$ $\left(\mathrm{NO}_{3} / \mathrm{NO}_{2}-\mathrm{N}\right)$ and total $\mathrm{N}$ (TN) using Environmental Protection Agency approved Standard Methods (Clesceri et al. 1998). To monitor daily water depth remotely and make decisions with regard to water quality sampling, we installed a telephone line and hooked it to a flowmeter and area velocity AV probe in site 1 .

\section{Figure 1}

Bayou Plaquemine Brule Watershed in Louisiana and the seven water quality monitoring locations in this study (map courtesy Louisiana Department of Environmental Quality Geographic Information Systems Unit).

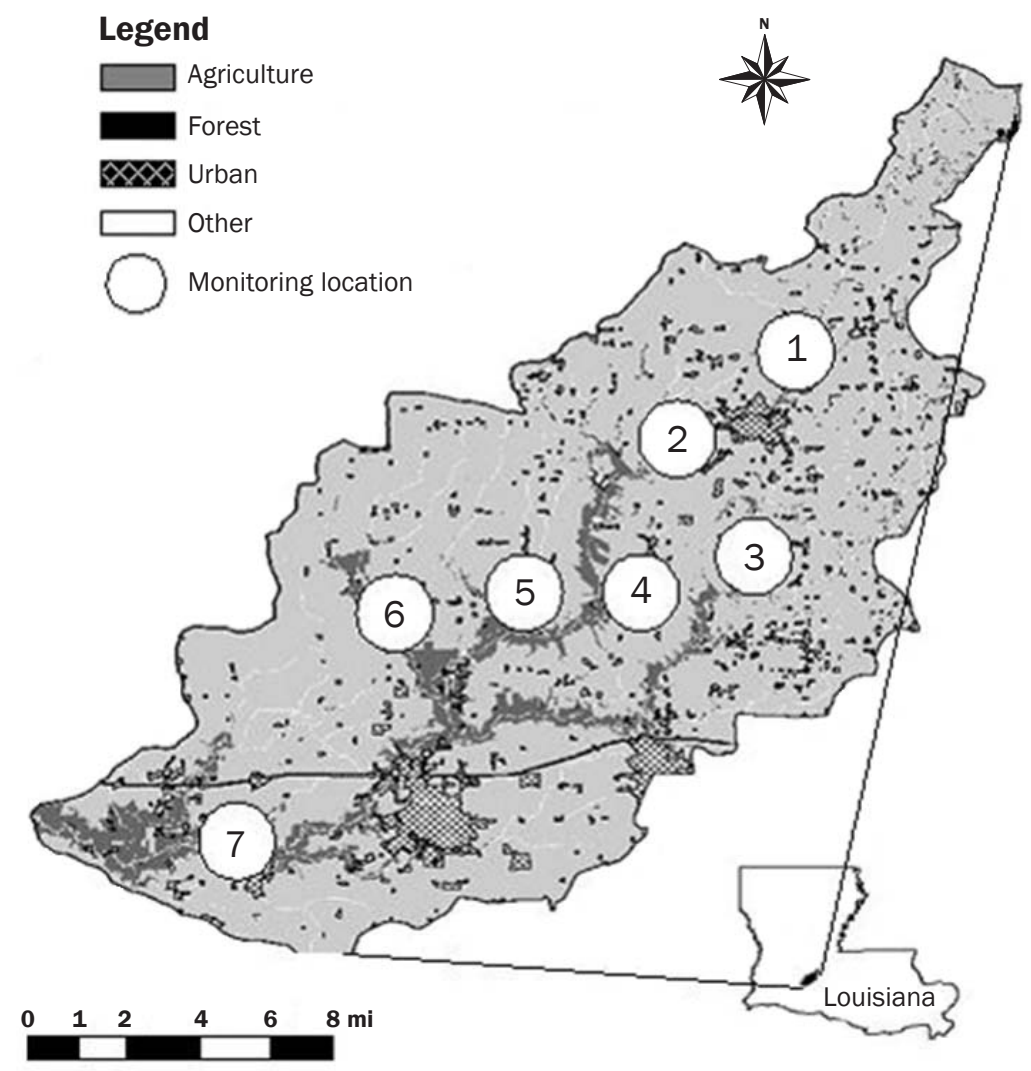

Dissolved oxygen, temperature, turbidity, conductivity, and $\mathrm{pH}$ were measured in the field with a multiprobe YSI Sonde (YSI Incorporated, Yellow Springs, Ohio) attached to a handheld data logger (YSI Sonde model 6820 with 650MDS). Field measurements were taken from the marked point at the bridge at each site at three different depths: $20 \%, 60 \%$, and $80 \%$ of the stream's depth from the surface. The YSI probes were calibrated, and the membranes for the oxygen $\left(\mathrm{O}_{2}\right)$ sensors were replaced prior to bringing them to field measurements. The YSI Sonde was cleaned after each measurement, and the probes were kept moist. To avoid diurnal variation on water quality, all the field measurements, water sampling, and water depth measurements were done generally at the same time of the day.

A large seasonal variation was noticed on water depth at seven monitoring locations during this study (figure 2). Average monthly water depth at site 1 ranged between 0.71 $\mathrm{m}(2.33 \mathrm{ft})$ in August to $1.65 \mathrm{~m}(5.41 \mathrm{ft})$ in
October, and for site 3 , it ranged between $0.08 \mathrm{~m}(0.26 \mathrm{ft})$ in August to $0.97 \mathrm{~m}(3.18$ $\mathrm{ft}$ ) in November. We frequently observed the bank full of water at the seven monitoring locations following heavy rain events. On the other hand, site 3 was generally dry, especially during the drought season. According to Winter (2007), it is important to have a groundwater discharge to much of the length of stream to maintain a base flow. The low flow condition in Bayou Plaquemine Brule is caused by several factors, including extended drought, heavy groundwater withdrawal for rice cultivation, seepage to groundwater, and loss of stream water due to evaporation.

Soil and Water Assessment Tool Modeling. The SWAT model (Arnold et al. 1998) was used for modeling water quality in this study. Input data, resolutions, and their sources for the SWAT model in this study are presented in table 1. Relevant information on planting, management, and harvest of agricultural crops such as sugarcane, soybean, corn, and rice and management information for pas- 
Figure 2

Average monthly depth of water at water quality monitoring locations in Bayou Plaquemine Brule Watershed, Louisiana, during monitoring duration, from 2002 to 2008: (a) site 1, (b) site 2, (c) site 3, (d) site 4, (e) site 5, and (f) site 6. Number of observations ( $(n)$ for each site for the months of January, November, and December is 12, April and October is 11, March and July is 10, and February is 13. For the month of May, site 1 had 11 observations, and the rest of the sites had 10 each. Similarly, for June, site 1 had 9 observations, and each of the other sites had 10 . Site 3 had 9 observations for the month of September, and rest of the sites had 10.

(a)

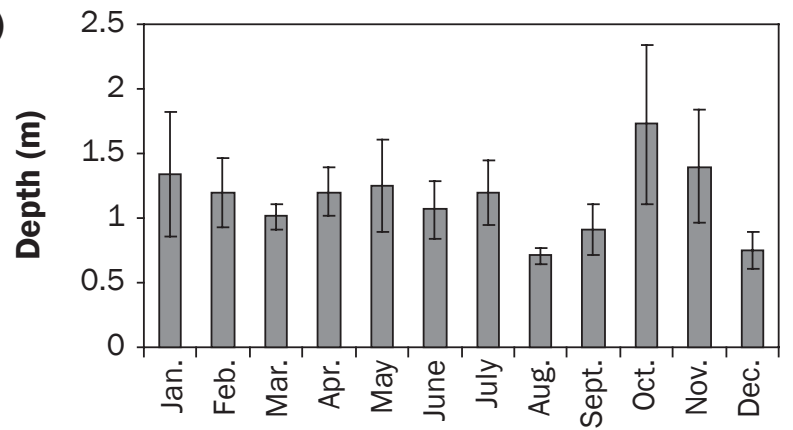

Month

(c)

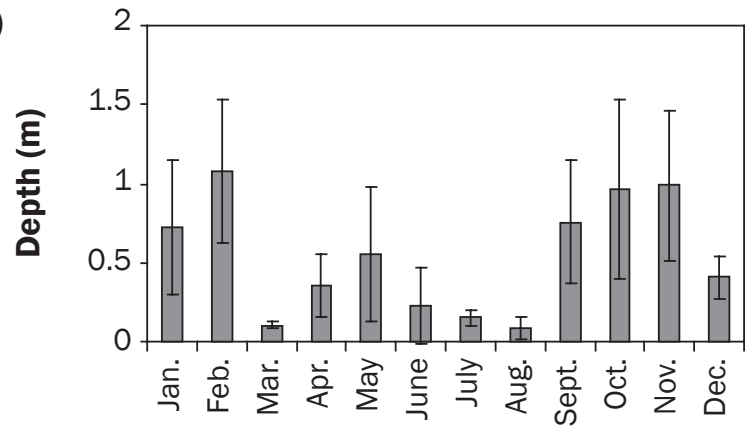

Month

(e)

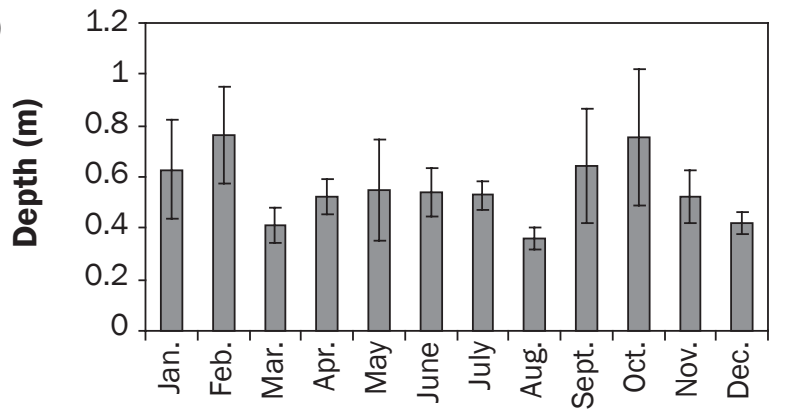

Month (b)

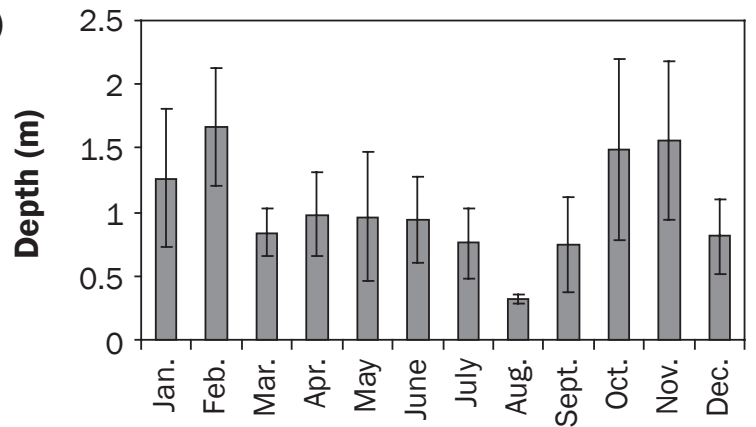

Month

(d)

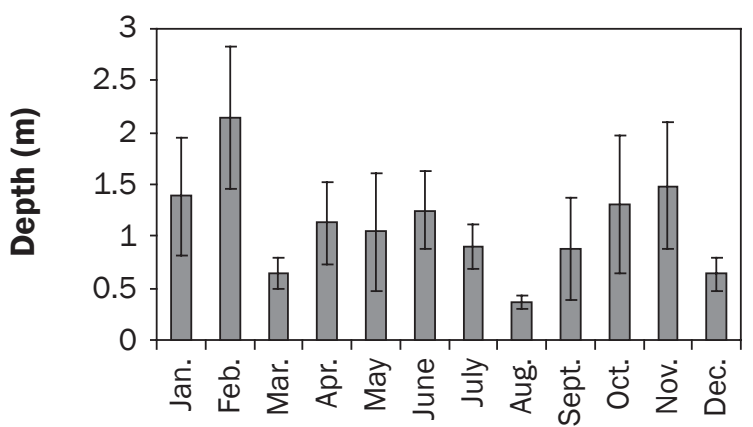

Month

(f)

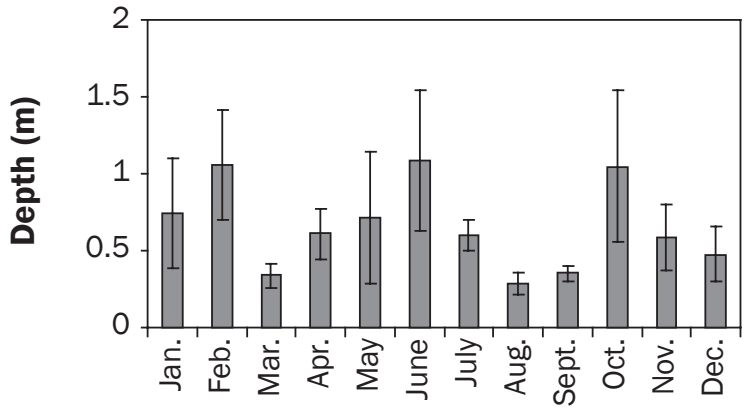

ture lands were collected from the available literature and by calling agronomists and cooperative extension agents in the region. Because the management practices across the watershed were quite similar, management data entry for the SWAT model was done at the subbasin level. Watershed outlets in the SWAT model were defined by forcing the seven monitoring locations as outlets, thus giving a total of seven subbasins in the watershed. Drainage areas and the number of the hydrological response units contained by these seven subbasins are presented in table 2 .

In the whole watershed, the daily discharge data was available only at an US Geological Survey station located nearby our water quality monitoring site 2 (figure $3)$. This dataset included the duration of May 1, 2002, to September 30, 2005, (table $1)$. Assuming that similar discharge rates exist between site 2 and the US Geological
Survey station, we used site 2 for flow, sediment, TN, and TP calibration, validations, and evaluations in this study. The flow calibration period included May 1, 2002, to December 31,2003 , and the flow validation period included January 1, 2004, to September 30, 2005. Flow calibration was done first. Then, the sensitivity analyses were conducted to find most sensitive parameters in the study area. The parameters were adjusted until observed and modeled flow were most 


\section{Table 1}

Model input data, resolution, and sources for Soil and Water Assessment Tool modeling of the Bayou Plaquemine Brule Watershed, Louisiana, United States.

\begin{tabular}{|c|c|c|}
\hline Input data & Resolution & Data source \\
\hline Digital Elevation Model & $5 \mathrm{~m}$ LIDAR & LIDAR, Atlas: The Louisiana Statewide GIS (LIDAR 2012) \\
\hline Soil data & 1998 STATSGO, 1:250,000 & US General Soil Map Data (USDA NRCS 2012) \\
\hline Land use map & 1998, Landsat TM (30 by $30 \mathrm{~m}$ ) & $\begin{array}{l}\text { LDEQ, Geographic Information Systems Unit, Baton Rouge, } \\
\text { Louisiana }\end{array}$ \\
\hline Precipitation and temperature & Average daily, 1980 to 2008 & $\begin{array}{l}\text { Louisiana State University AgCenter, Rice Research Station, } \\
\text { Crowley, Louisiana }\end{array}$ \\
\hline Discharge data & Average daily, May of 2002 to September of 2005 & Instantaneous Data Archive (USGS 2012) \\
\hline Agronomic management & Watershed level & Agronomists and cooperative extension agents in the region \\
\hline
\end{tabular}

closely matched in the optimization process. While the total and average flow for the calibration and validation duration period were reasonably close (table 3 ), the $r^{2}$ values of 0.51 for calibration and 0.32 for flow validation were lower than we had expected (figure 4). However, we believe that this level of model robustness is fairly good enough for targeting critical areas of nonpoint source pollution for sediments, $\mathrm{N}$, and $\mathrm{P}$, especially at the subbasin level. The simulated flow closely followed the pattern of the observed flow. Geza and McCray (2008) found State Soil Geographic Data Base (STATSGO) soil data provided better results than the Soil Survey Geographic Database (SSURGO) soil dataset for flow before calibration, and SSURGO provided better results for flow after flow calibration. Therefore, the $r^{2}$ value, especially in validation, was affected by soil dataset since we used STATSGO soil data in this study. In addition, the SWAT model is quite sensitive to the soil dataset and the accurate representation of land use types (Romanowicz et al. 2005; Geza and McCray 2008). The assumption of crawfish ponds as rice fields in this study obviously has affected the model performance. There is no crop production item such as crawfish or rice/crawfish production in the current versions of the SWAT model.

Among all the optimized parameters for flow, sediment, TN, and TP (table 4), the groundwater delay (GW_DELAY) was the most sensitive parameter, followed by sediment concentration in lateral and ground water flow for sediment (LAT_SED), percolation coefficient for N (N_PERCO), and rate constant for mineralization of organic $\mathrm{P}$ to dissolved $\mathrm{P}$ for $\mathrm{P}$ (BC4). The high sensitivity of the GW_DELAY is primarily due to the flat topography as well as heavy withdrawal of groundwater for crawfish and rice production in this study area. The value for GW_DELAY was increased to 400 days.

\section{Table 2}

Drainage areas and the number of hydrological response units (HRUs) as identified by the Soil and Water Assessment Tool model for the seven subbasins corresponding with the water quality monitoring sites in Bayou Plaquemine Brule Watershed, Louisiana.

\begin{tabular}{llllllll}
\hline & \multicolumn{7}{l}{ Subbasin } \\
\cline { 2 - 7 } Parameter & $\mathbf{1}$ & $\mathbf{2}$ & $\mathbf{3}$ & $\mathbf{4}$ & $\mathbf{5}$ & $\mathbf{6}$ & $\mathbf{7}$ \\
\hline Area (ha) & 9,807 & 16,610 & 7,782 & 25,760 & 2,824 & 6,933 & 78,130 \\
Number of HRU & 4 & 3 & 3 & 6 & 12 & 6 & 14
\end{tabular}

\section{Figure 3}

Flow calibration and validation and sediments and nutrients evaluation at site 2, a site nearby the US Geological Survey (USGS) gauging station at Bayou Plaquemine Brule Watershed, Louisiana.

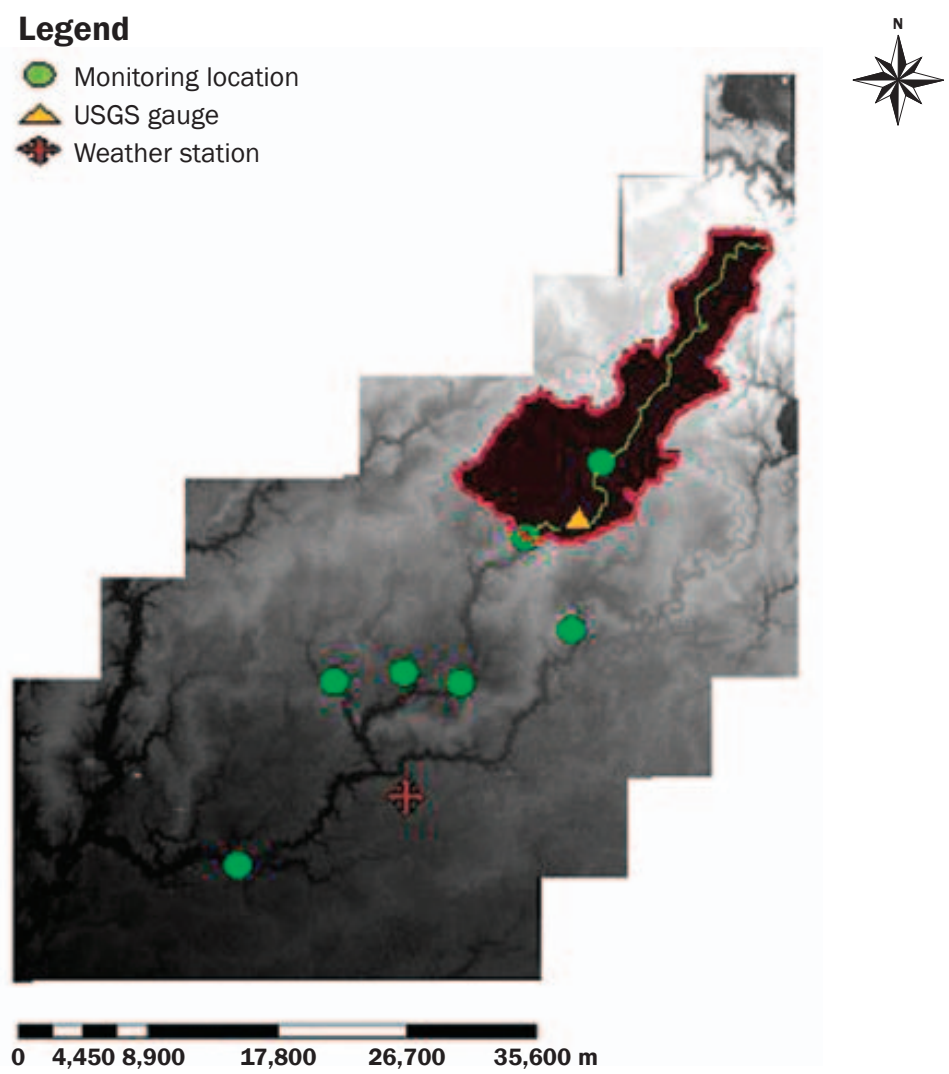


Table 3

Total and monthly average flow $\left(\mathrm{m}^{3} \mathrm{~s}^{-1}\right)$ for calibration (May of 2002 to December of 2003) and validation period (January of 2004 to September of 2005).

\begin{tabular}{llllll}
\hline & \multicolumn{2}{l}{ Calibration } & & & \\
\cline { 2 - 3 } \cline { 5 - 6 } Parameter & Observed & Modeled & & Observed & Modeled \\
\hline Total & 90.48 & 83.00 & & 102.87 & 125.87 \\
Monthly average & 4.52 & 4.15 & 4.90 & 5.99 \\
\hline
\end{tabular}

\section{Figure 4}

Monthly observed and modeled flow during the calibration (to the left of vertical line; $r^{2}=0.51$ ) and the validation (to the right of vertical line; $r^{2}=0.32$ ) period for the US Geological Survey gauge station nearby site 2 in Bayou Plaquemine Brule Watershed, Louisiana.

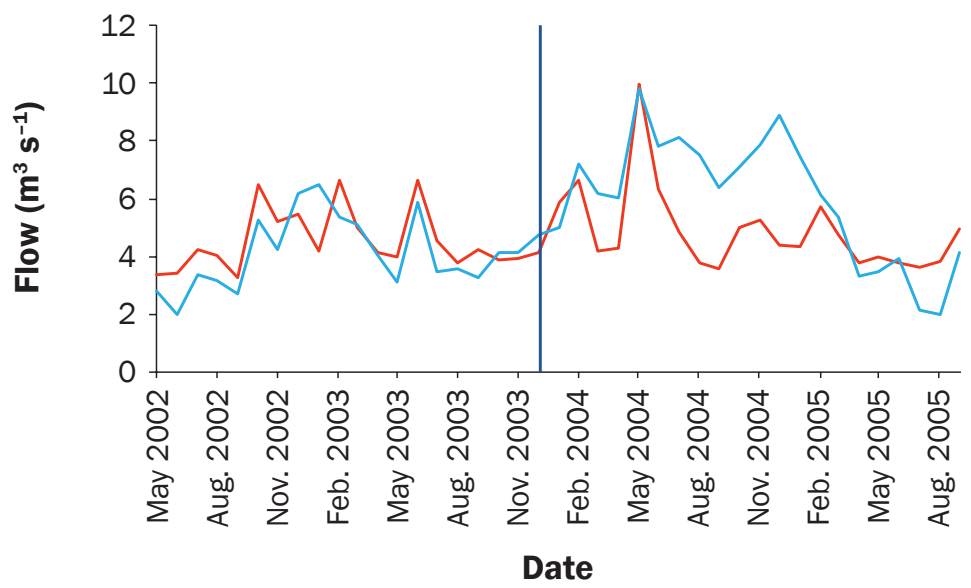

Legend

- Observed - Modeled
Model evaluation for sediment, TN, and TP was accomplished by comparing modeled values and observed values for the duration of May 1, 2002, to September 30, 2005 , with respect to total mass and average values (table 5). Simulations were done only for observed days during the simulation period.Total estimated mass ( $88.4 \mathrm{t}$ [97.4 tn]) and average mass $(1.1 \mathrm{t}$ [1.2 tn]) for sediment for those days $(n=82)$ were very close to the observed mass $(88.2 \mathrm{t}$ [97.2 tn]) and average mass $(1.1 \mathrm{t}$ ) (table 5). The TN was overestimated by $1,298.1 \mathrm{~kg}(2,861 \mathrm{lb})$ on total mass and $18.8 \mathrm{~kg}(41.4 \mathrm{lb})$ on average mass $(n=$ 82), while TP was underestimated by 121.9 $\mathrm{kg}(268.7 \mathrm{lb})$ on total mass and $1.7 \mathrm{~kg}(3.7$ lb) on average mass $(n=82)$ for the simulation period.

Optimized parameters were applied to the whole watershed with site 7 as watershed outlet for sediment, TN, and TP simulations from May 1, 2002, to September 30, 2005. The critical areas of sediment, TN, and TP were determined considering their annual loads. Uncertainty analysis of model calibration and validation for the flow was accomplished using a Sequential Uncertainty Fitting parameter optimization algorithm that uses Latin Hypercule Sampling approach (Abbaspour et al. 2004; Abbaspour et al. 2007).

Statistical Analysis. Because the Bayou Plaquemine Brule total maximum daily

\section{Table 4}

List of parameter values after adjustment for model calibration including flow, sediment, and nutrients. It should be noticed that groundwater delay in flow parameter was very high (400 days) and this seems to be because the groundwater in this area has been used for crawfish and rice production and has not been used as a recharging channel.

\begin{tabular}{|c|c|c|c|}
\hline Component & Parameter (file) & Description & Input value \\
\hline \multirow[t]{5}{*}{ Flow } & CN2 (.mgt) & SCS runoff curve number (adjustment range) & -5 to -20 \\
\hline & ESCO (.hru) & Soil evaporation factor & 0.9 \\
\hline & GW_DELAY (.gW) & Groundwater delay time $(\mathrm{d})$ & 400 \\
\hline & GWQMN (.gw) & Groundwater storage required for return flow $(\mathrm{mm})$ & 1 \\
\hline & SOL_K (.sol) & Soil hydrologic conductivity $\left(\mathrm{mm} \mathrm{h}^{-1}\right)$ & 10 \\
\hline \multirow[t]{5}{*}{ Sediment } & LAT_SED (.hru) & Sediment concentration in lateral and ground water flow $\left(\mathrm{mg} \mathrm{L}^{-1}\right)$ & 10 \\
\hline & SPCON (.bsn) & Linear parameter for calculating the maximum amount of sediment that can be reentrained & 0.0011 \\
\hline & SPEXP (.bsn) & Exponent parameter for calculating sediment reentrained & 1.2 \\
\hline & CH_COV (.rte) & Channel cover factor & 0.5 \\
\hline & CH_EROD (.rte) & Channel erodibility factor & 0.5 \\
\hline \multirow[t]{4}{*}{$\overline{\mathrm{N}}$} & N_PERCO (.bsn) & N percolation coefficient & 0.9 \\
\hline & $\mathrm{BC} 1(. \mathrm{swq})$ & Rate constant for biological oxidation of $\mathrm{NH}_{4}$ to $\mathrm{NO}_{2}$ (per day) & 0.01 \\
\hline & BC3 (.swq) & Rate constant for hydrolysis of organic $\mathrm{N}$ to $\mathrm{NH}_{4}$ (per day) & 0.1 \\
\hline & RS3 (.swq) & Benthic source rate for $\mathrm{NH}_{4}-\mathrm{N}$ & 0.1 \\
\hline \multirow[t]{3}{*}{$\bar{P}$} & PSP (.bsn) & $P$ availability index & 0.1 \\
\hline & RS2 (.swq) & Benthic source rate for dissolved $\mathrm{P}$ & 0.3 \\
\hline & BC4 (.swq) & Rate constant for mineralization of organic $\mathrm{P}$ to dissolved $\mathrm{P}$ & 0.7 \\
\hline
\end{tabular}

Notes: $\mathrm{N}=$ nitrogen. $\mathrm{NH}_{4}=$ ammonium. $\mathrm{NO}_{2}=$ nitrite. $\mathrm{P}=$ phosphorus. 


\section{Table 5}

Total mass and average of observed and modeled sediment and nutrients for only sampling dates during the modeling period $(n=82)$.

\begin{tabular}{|c|c|c|c|c|c|c|}
\hline \multirow{2}{*}{$\begin{array}{l}\text { (May 1, 2002, to } \\
\text { Sept. 30, 2005) }\end{array}$} & \multicolumn{2}{|c|}{ Sediment (t) } & \multicolumn{2}{|l|}{ TN (kg) } & \multicolumn{2}{|l|}{ TP (kg) } \\
\hline & Observed & Modeled & Observed & Modeled & Observed & Modeled \\
\hline Total mass & 88.2 & 88.4 & $3,160.0$ & $4,458.1$ & 519.6 & 397.7 \\
\hline Average & 1.1 & 1.1 & 45.8 & 64.6 & 7.5 & 5.8 \\
\hline
\end{tabular}

Notes: $\mathrm{TN}=$ total nitrogen. $\mathrm{TP}=$ total phosphorous

\section{Table 6}

Average values of surface water quality parameters (five-day biological oxygen demand [BOD ${ }_{5}$, total suspended solids [TSS], nitrate/nitrite-nitrogen $\left[\mathrm{NO}_{3} / \mathrm{NO}_{2}-\mathrm{N}\right.$ ], total nitrogen [TN], soluble reactive phosphate [SRP], total phosphorus [TP], temperature, conductivity, $\mathrm{pH}$, turbidity, dissolved oxygen [DO], total combustible solids [TCS], and total Kjeldahl nitrogen [TKN]) for summer months (March to November) and the winter months (December to February) in Bayou Plaquemine Brule Watershed, Louisiana, from 2002 to 2008.

\begin{tabular}{lllll}
\hline Parameter & $\mathbf{n}$ & $\begin{array}{l}\text { Summer } \\
\text { mean }\end{array}$ & $\mathbf{n}$ & $\begin{array}{l}\text { Winter } \\
\text { mean }\end{array}$ \\
\hline $\mathrm{BOD}_{5}\left(\mathrm{mg} \mathrm{L}^{-1}\right)$ & 718 & $5.30( \pm 0.13)^{* * *}$ & 252 & $3.22( \pm 0.11)^{* * *}$ \\
$\mathrm{TSS}\left(\mathrm{mg} \mathrm{L}^{-1}\right)$ & 730 & $100.67( \pm 4.56)^{*}$ & 259 & $79.72( \pm 8.76)^{*}$ \\
$\mathrm{NO}_{3} / \mathrm{NO}^{-} \mathrm{N}\left(\mathrm{mg} \mathrm{L}^{-1}\right)$ & 718 & $1.34( \pm 0.05)^{* * *}$ & 259 & $0.89( \pm 0.04)^{* * *}$ \\
$\mathrm{TN}\left(\mathrm{mg} \mathrm{L}^{-1}\right)$ & 634 & $3.23( \pm 0.07)^{* * *}$ & 259 & $2.40( \pm 0.07)^{* * *}$ \\
$\mathrm{SRP}\left(\mathrm{mg} \mathrm{L}^{-1}\right)$ & 655 & $0.31( \pm 0.01)^{* * *}$ & 259 & $0.23( \pm 0.01)^{* * *}$ \\
$\mathrm{TP}\left(\mathrm{mg} \mathrm{L}^{-1}\right)$ & 634 & $0.43( \pm 0.01)^{* * *}$ & 259 & $0.33( \pm 0.01)^{* * *}$ \\
Temperature $\left({ }^{\circ} \mathrm{C}\right)$ & 734 & $23.1( \pm 0.2)^{* * *}$ & 257 & $12.6( \pm 0.2)^{* * *}$ \\
Conductivity $\left(\mathrm{mS} \mathrm{cm}^{-1}\right)$ & 733 & $0.57( \pm 0.01)^{* * *}$ & 257 & $0.44( \pm 0.02)^{* * *}$ \\
$\mathrm{pH}$ & 720 & $7.58( \pm 0.01) \mathrm{ns}$ & 235 & $7.61( \pm 0.04) \mathrm{ns}$ \\
Turbidity (NTU) & 734 & $203.9( \pm 13.6) \mathrm{ns}$ & 257 & $168.8( \pm 12.3) \mathrm{ns}$ \\
DO $\left(\mathrm{mg} \mathrm{L}^{-1}\right)$ & 729 & $4.91( \pm 0.08)^{* * *}$ & 257 & $8.32( \pm 0.12)^{* * *}$ \\
TCS $\left(\mathrm{mg} \mathrm{L}^{-1}\right)$ & 236 & $58.05( \pm 5.69) \mathrm{ns}$ & 91 & $46.55( \pm 6.03) \mathrm{ns}$ \\
TKN $\left(\mathrm{mg} \mathrm{L}^{-1}\right)$ & 620 & $2.11( \pm 0.06)^{* * *}$ & 210 & $1.64( \pm 0.09)^{* * *}$ \\
\hline
\end{tabular}

Note: Means followed by ns are not significantly different at 0.05 probability level by the two sample student's $t$-test with independent sample.

$* p<.05 * * p<.01 * * * p<.001$

loads report divides months into two seasons, December through February as winter months and March through November as the summer months (Berger, Jr. et al. 2000), we analyzed our dataset considering the two seasons in this study. Seasonal and spatial variation of surface water quality parameters were determined by comparing means between the summer and the winter months by two sample student $t$-tests for independent samples and by the analysis of variance (ANOVA) in Statistical Analysis Systems (SAS 2003). Mean comparisons among the seven sites were done using a StudentNewman-Keuls test at 0.05 probability level. Along with the calculation of statistics such as averages, standard error, median, and range for the water quality parameters, the principal component analysis and the factor analysis were performed in JMP 8.0 Factors were identified after varimax rotation of the principle components. Principal component and factors analyses were done for untransformed data as well as for transformed data using square root, natural log, and inverse transformations. These analyses were conducted for winter and summer seasons separately as well as for the whole year.

\section{Results and Discussion}

Seasonal Variation. Surface water quality of the Bayou Plaquemine Brule Watershed showed significant differences between the summer and the winter season. On average, the summer season had significantly higher values for $\mathrm{BOD}_{5}$, TSS, total Kjeldahl $\mathrm{N}$ (TKN), TN, $\mathrm{NO}_{3} / \mathrm{NO}_{2}-\mathrm{N}, \mathrm{SRP}, \mathrm{TP}$, water temperature, and conductivity, and the win- ter season had significantly higher average value for DO (table 6). While average DO concentration for the summer months was $4.91 \pm 0.08 \mathrm{mg} \mathrm{L}^{-1}(4.91 \pm 0.08 \mathrm{ppm})$, average DO concentration for the winter months was $8.32 \pm 0.12 \mathrm{mg} \mathrm{L}^{-1}$ (8.32 \pm 0.12 $\mathrm{ppm})$. Summer DO values ranged between 0.43 and $12.97 \mathrm{mg} \mathrm{L}^{-1}$ (0.43 and 12.97 ppm), while the winter DO values ranged between 3.01 and $12.67 \mathrm{mg} \mathrm{L}^{-1}$ (3.01 and $12.67 \mathrm{ppm})$. These results suggest that surface water quality in the Bayou Plaquemine Brule Watershed occasionally reached the critical threshold level, especially in the summer months due to low level of DO. Low DO concentration in surface water in the summer months is associated with higher surface water temperatures and agricultural activities, such as crop planting, fertilizer application, and crop harvesting, in these months. Similar results in terms of nutrient concentrations and seasonality are reported by Demcheck et al. (2004) in southwestern Louisiana. They found maximum concentrations of TN and TP occurring during April through June and minimum concentrations occurring during the fall and the winter months.

Figure 5 shows the variation of the surface water quality parameters between the summer and the winter season in terms of median, 25th percentile, and 75th percentile. While the median concentration of TSS in summer time was as high as $60.6 \%$ of the winter TSS median concentration, the $\mathrm{BOD}_{5}, \mathrm{TKN}, \mathrm{NO}_{3} / \mathrm{NO}_{2}-\mathrm{N}, \mathrm{TN}, \mathrm{SRP}, \mathrm{TP}$, and conductivity median values for the summer season were respectively $42.5 \%, 30.8 \%, 46.7 \%$, $31.8 \%, 19.1 \%, 26.8 \%$, and $18.2 \%$ higher compared to the corresponding winter season median values. Summer median DO values were $45.6 \%$ lower compared to the winter median DO values. Similarly, the 75th percentile values of $6.1,123,2.5,1.7,3.7,0.37$, and 0.52 , respectively, for $\mathrm{BOD}_{5}, \mathrm{TSS}, \mathrm{TKN}$, $\mathrm{NO}_{3} / \mathrm{NO}_{2}-\mathrm{N}, \mathrm{TN}, \mathrm{SRP}$, and TP in the summer were remarkably higher as compared to their corresponding 75 th percentile values of $4,92,1.7,1.3,2.8,0.29$, and 0.39 in winter. These results indicate the elevated level of nonpoint source pollution in the summer season compared to the winter season in Bayou Plaquemine Brule Watershed.

As expected, rain events impacted on surface water quality parameters both in the summer and in the winter months (figure 6). However, some parameters were affected 
Figure 5

Water quality characteristics of Bayou Plaquemine Brule for the summer (March through November) and winter (December through February) months. Values for (a) five-day biological oxygen demand (BOD), (b) total suspended solids (TSS), (c) total combustible solids (TCS), (d) total Kjeldahl nitrogen (TKN), (e) total nitrogen (TN), (f) nitrate/nitrite-nitrogen $\left(\mathrm{NO}_{3} / \mathrm{NO}_{2}-\mathrm{N}\right)$, (g) soluble reactive phosphate (SRP), (h) total phosphorus (TP), (i) temperature, (j) conductivity, ( $\mathrm{k}$ ) turbidity, (l) $\mathrm{pH}$, and $(\mathrm{m})$ dissolved oxygen (DO) are included. Median, 25th percentile, and $75^{\text {th }}$ percentile values are shown for each variable.

(a)

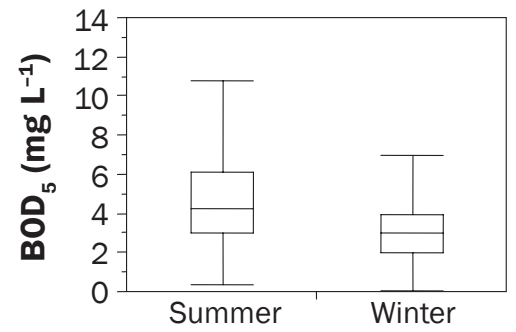

(d)

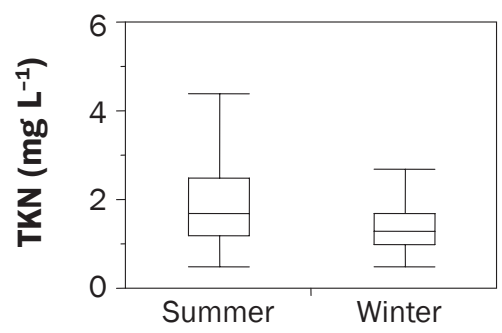

(g)

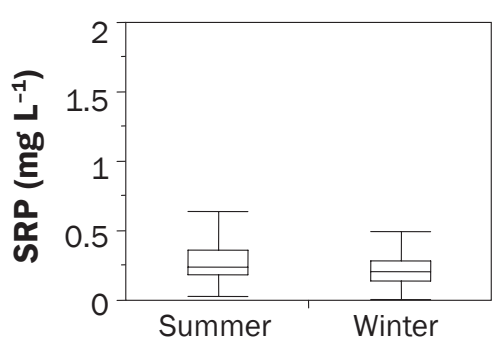

(j)

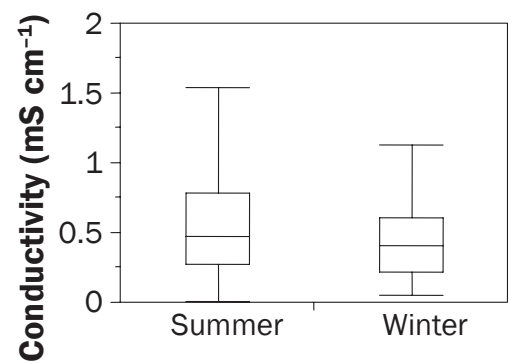

(k)

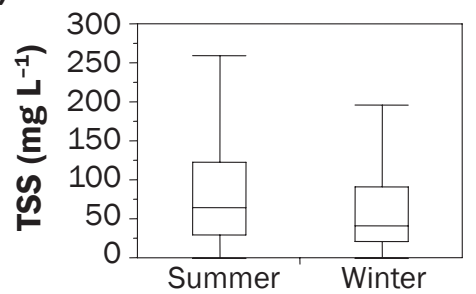

(e)

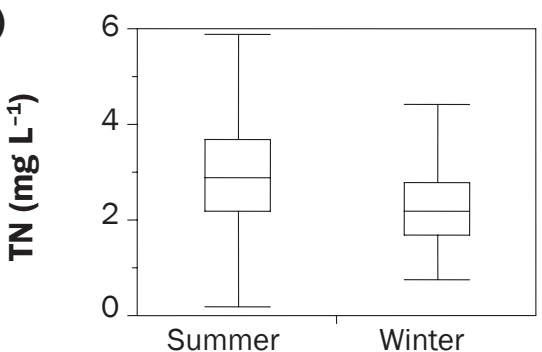

(h)
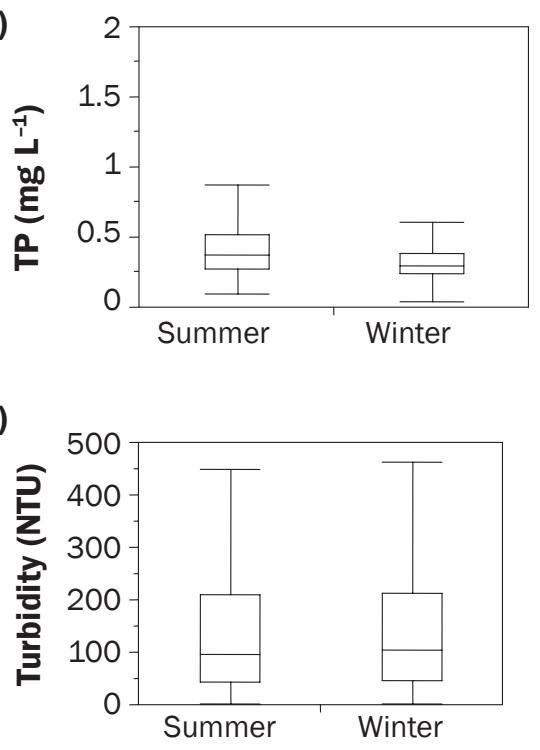

(c)

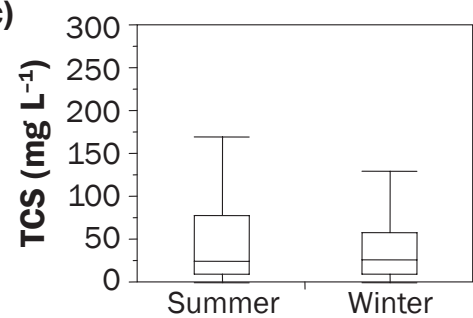

(f)

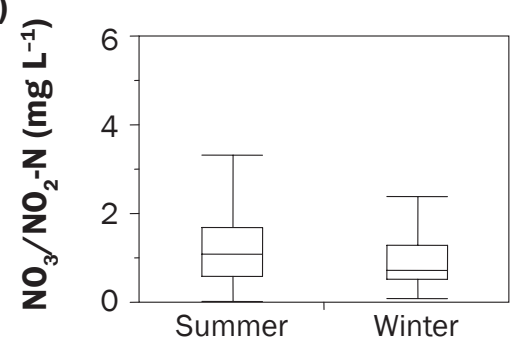

(i)

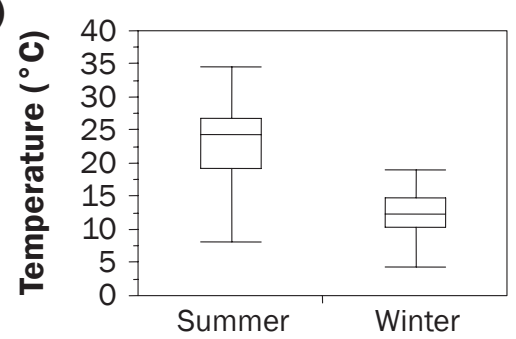

(I)

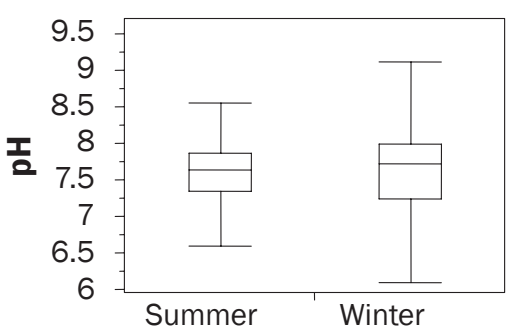

(m)

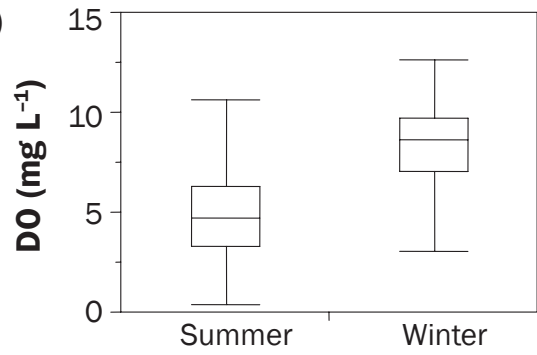




\section{Figure 6}

Water quality characteristics of Bayou Plaquemine Brule for the summer (March through November) and winter (December through February) regular and after-the-rain events (summer regular [SR], summer rain event [SERV], winter regular [WR], and winter rain event [WREV]). Values for (a) five-day biological oxygen demand (BOD), (b) total suspended solids (TSS), (c) total combustible solids (TCS), (d) total Kjeldahl nitrogen (TKN), (e) nitrate/nitrite-nitrogen $\left(\mathrm{NO}_{3} / \mathrm{NO}_{2}-\mathrm{N}\right)$, (f) total nitrogen ( $\left.\mathrm{TN}\right)$, (g) soluble reactive phosphate (SRP), (h) total phosphorus (TP), (i) temperature, (j) conductivity, (k) pH, (l) turbidity, and (m) dissolved oxygen (DO) are included. Median, 25th percentile, and 75th percentile values are shown for each variable.

(a)

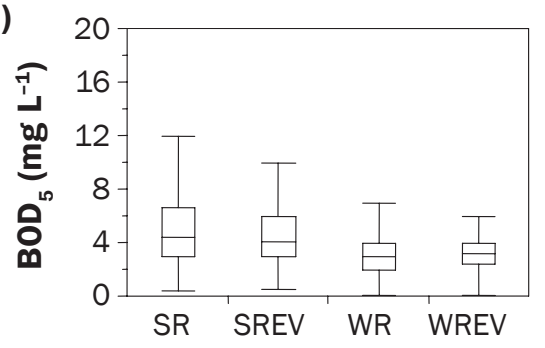

(d)

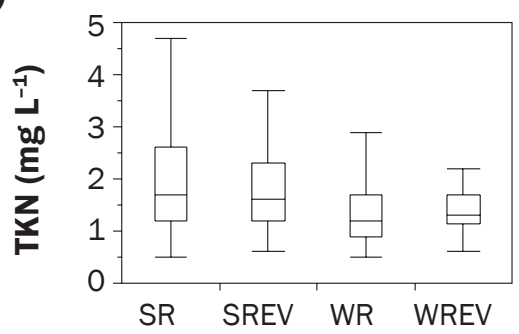

(g)

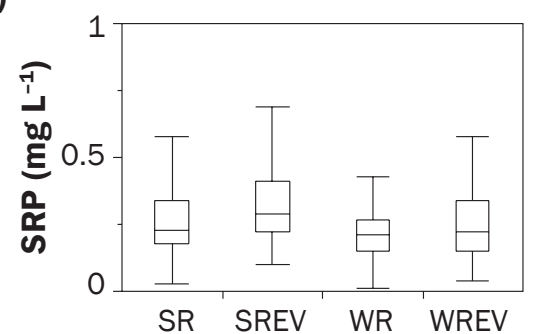

(j)

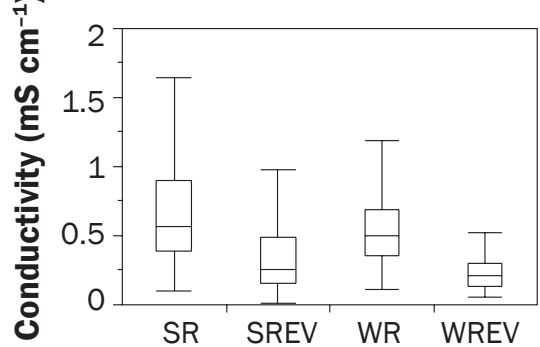

(b)

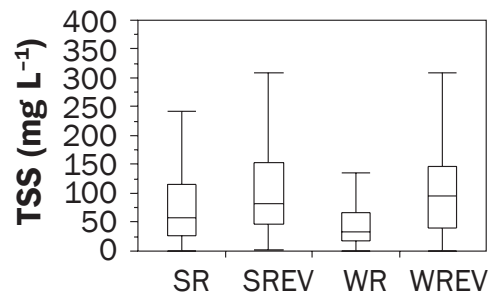

(e)

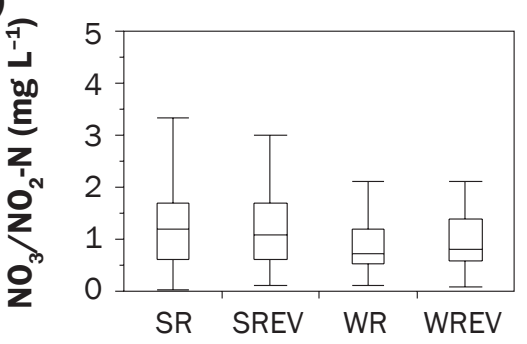

(h)

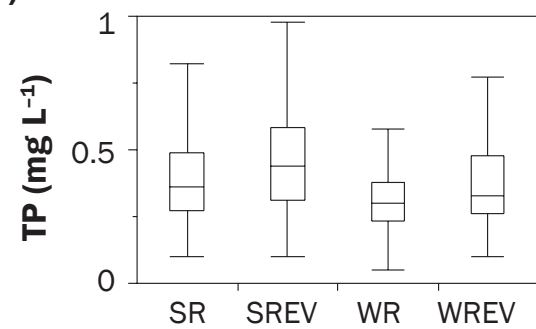

(k)

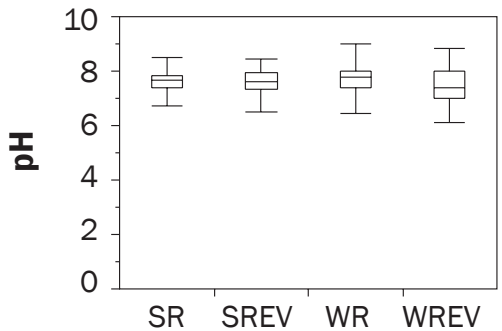

(c)

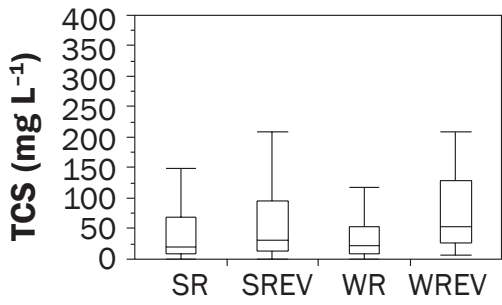

(f)

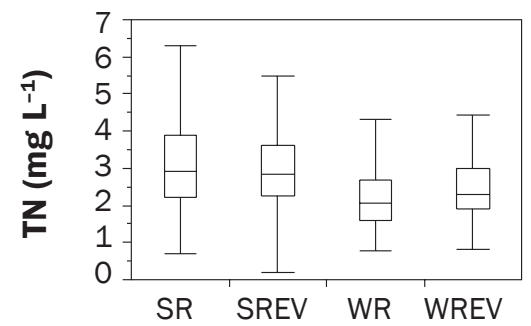

(i)

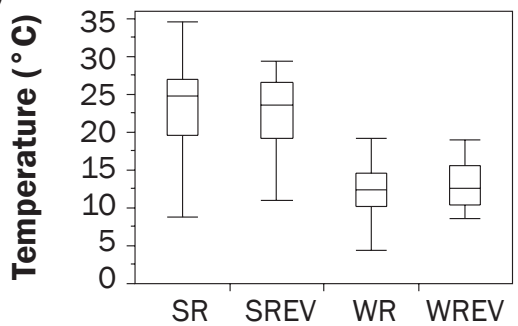

(l)

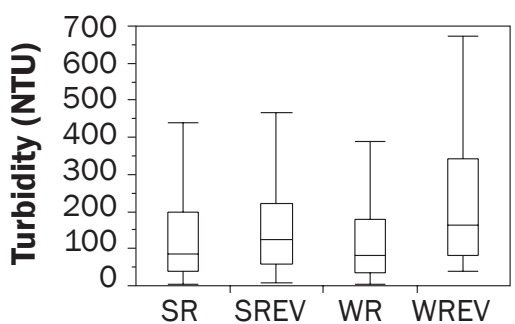

(m)

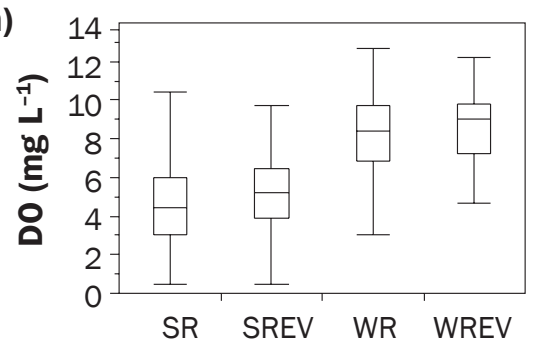




\section{Figure 7}

Average monthly values of field water quality parameters ([a] temperature, [b] conductivity, [c] pH, [d] turbidity, and [e] dissolved oxygen [DO]) in Bayou Plaquemine Brule Watershed, Louisiana, from March of 2002 to February of 2008.

(a)

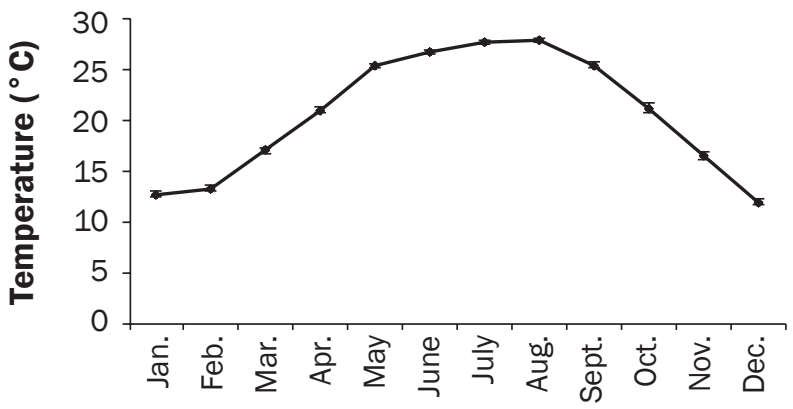

Month

(c)

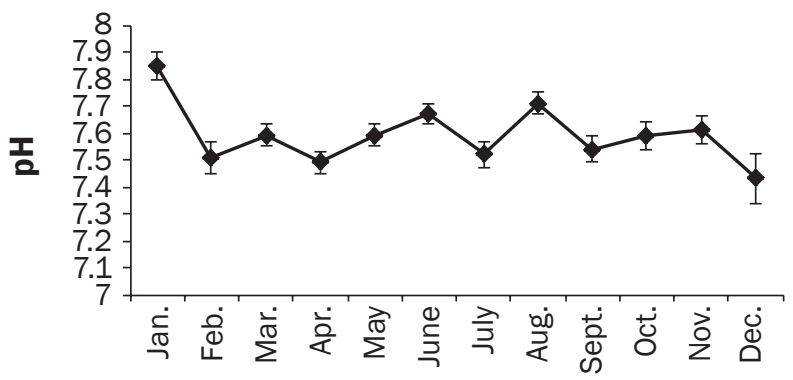

Month

(e)

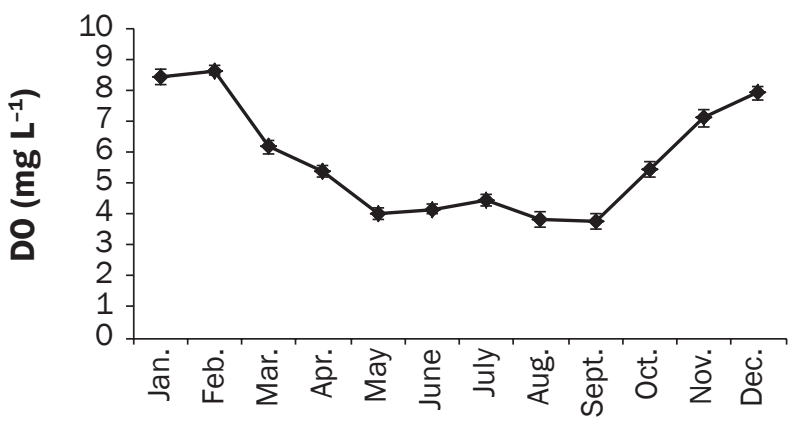

(b)

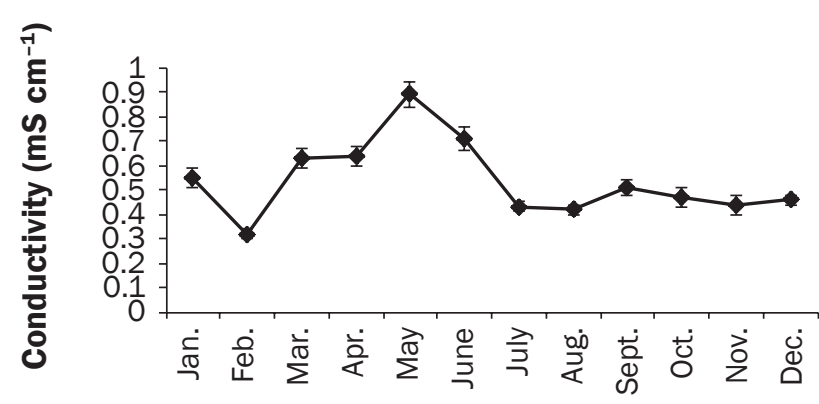

Month

(d)

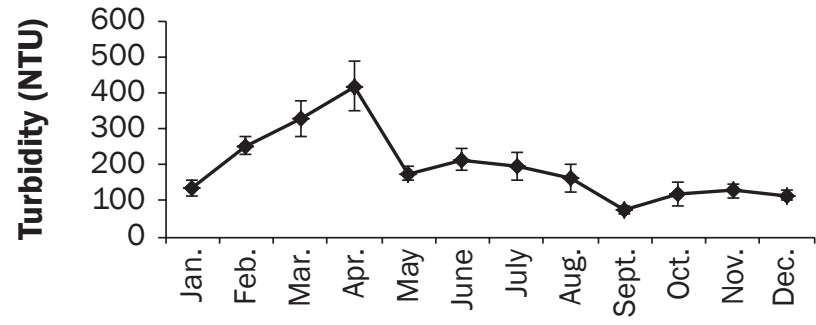

Month

more in one season than the others. In both seasons, significantly higher concentrations of TSS $(p \leq 0.001)$, SRP $(p \leq 0.05)$, and DO $(p$ $\leq 0.05)$ and significantly lower concentration of conductivity $(p \leq 0.001)$ were observed following the rain events compared to the regular sampling events. As compared to the background sampling, the after-rain-events sampling showed significantly higher averages for $\mathrm{BOD}_{5}$, total combustible solids (TCS), TP, and turbidity concentrations in winter and lower average $\mathrm{NO}_{3} / \mathrm{NO}_{2}-\mathrm{N}$ concentration in summer. There was no significant difference at 0.05 alpha levels on the average concentration of TN and TKN and average water temperature between regular and rain-event samplings for both seasons. These results, especially the higher TSS, SRP, and TP concentrations following the rain events, indicate that nonpoint source pollution is a major problem in the watershed. Increased stream concentrations of TSS, SRP, and TP following storm events are reported by other researchers (Gelbrecht et al. 2005; Hongbing et al. 2009). Increased concentrations of BOD ${ }_{5}$, TSS, TCS, $\mathrm{TP}$, and turbidity following the rain events in winter months were largely associated with the harvesting of sugarcane, rice, crawfish, and preparation of lands in the fall for subsequent crops. These results suggest that appropriate crop harvesting techniques and the better management of crop fields after harvest are necessary for reducing nonpoint source pollution in the watershed.

Except for $\mathrm{pH}$, surface water quality in Bayou Plaquemine Brule Watershed showed considerable monthly variations (figures 7 and 8). Monthly average values for TSS ranged between 51.52 and $182.21 \mathrm{mg} \mathrm{L}^{-1}$ (51.52 and $182.21 \mathrm{ppm})$ during the summer months when rice fields and crawfish ponds were drained, and 52.73 and 94.76 $\mathrm{mg} \mathrm{L}^{-1}$ (52.73 and $94.76 \mathrm{ppm}$ ) for the winter months. Coinciding with agricultural activities in the watershed, especially land 


\section{Figure 8}

Average monthly values of laboratory water quality parameters ([a] five-day biological oxygen demand [BOD $]$; [b] total suspended solids [TSS] and total combustible solids [TCS]; [c] total nitrogen [TN], total Kjeldahl nitrogen [TKN], and nitrate/nitrite-nitrogen [ $\mathrm{NO}_{3} / \mathrm{NO}_{2}-\mathrm{N}$ ]; and [d] total phosphorus [TP] and soluble reactive phosphate [SRP]) in Bayou Plaquemine Brule Watershed, Louisiana, from March of 2002 to February of 2008.

(a)

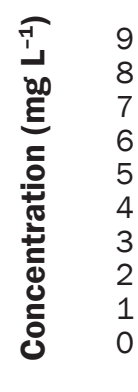

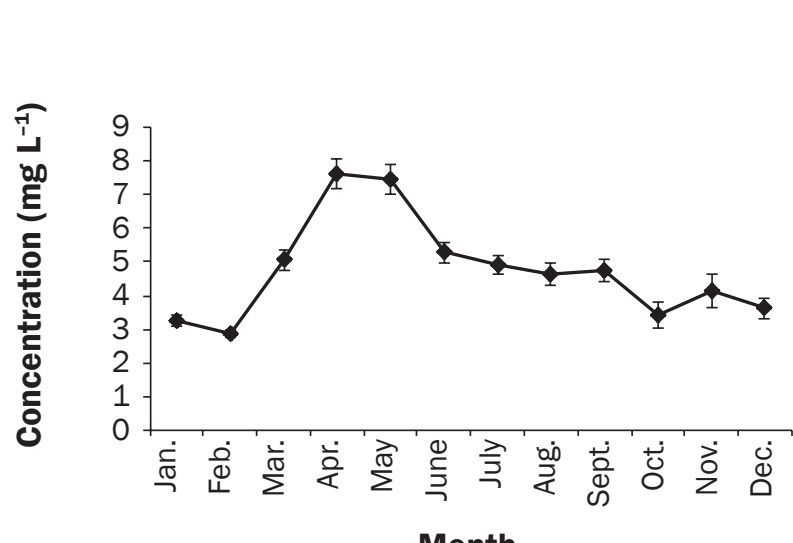

Legend

$\rightarrow \mathrm{BOD}_{5}$

(c)

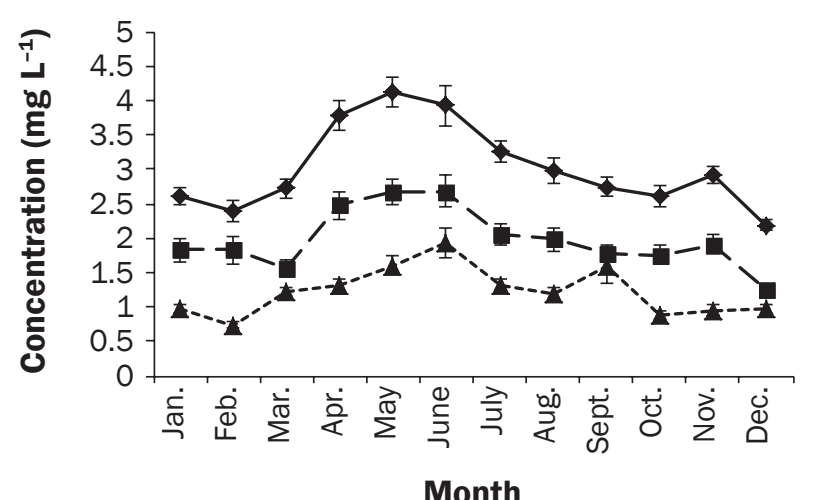

Legend

$\longrightarrow \mathrm{TN} \quad \longrightarrow-\mathrm{TKN} \quad \cdots \mathrm{NO}_{3} / \mathrm{NO}_{2}-\mathrm{N}$

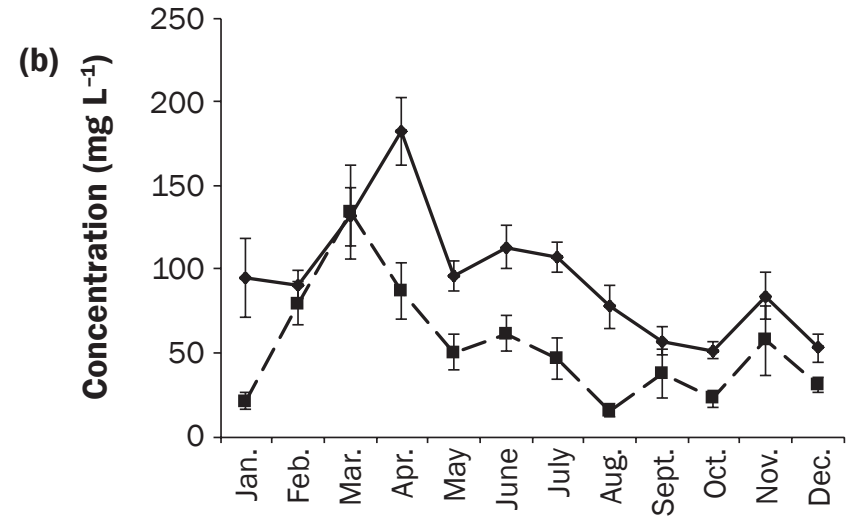

Month

\section{Legend}

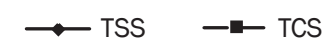

(d)

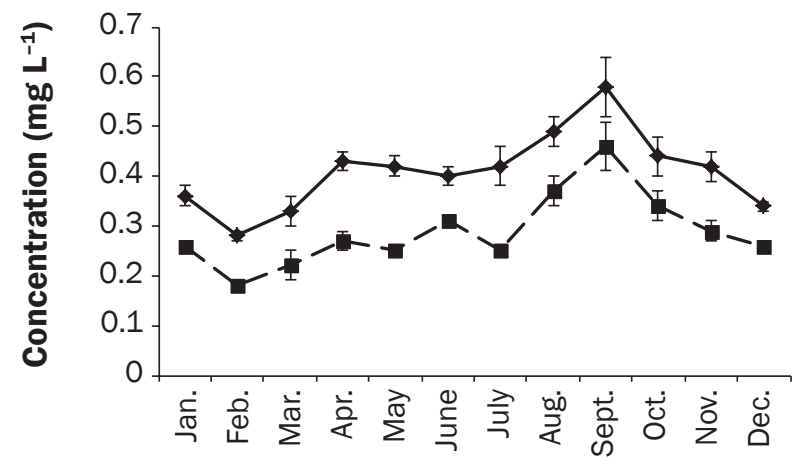

Month

\section{Legend}

$\because \mathrm{TP} \quad \longrightarrow$ SRP

preparation for crop planting, average TSS value for the watershed was significantly higher in the month of April compared to any other months. Similarly, TN values for the months of April, May, and June were significantly higher compared to the rest of the months. August and September showed significantly higher values for SRP and TP compared to the rest of the months. These results indicate that the months of March and April were the major months for TSS pollution; April, May, June, and July for $\mathrm{N}$ pollution; and August, September, and October for $\mathrm{P}$ pollution in this watershed.
Spatial Variation. Surface water quality differed greatly among the seven water quality monitoring locations in Bayou Plaquemine Brule Watershed (table 7). While sites 4,5 , and 6 showed higher levels of TSS concentration, site 2 showed higher levels of $\mathrm{TN}, \mathrm{NO}_{3} / \mathrm{NO}_{2}-\mathrm{N}, \mathrm{TP}$, and SRP concentrations, and site 7 showed the least level of DO. Average TSS concentration for sites 4, 5, and 6 , respectively, were $119.38,140.25$, and $118.41 \mathrm{mg} \mathrm{L}^{-1}$ (119.38, 140.25, and 118.41 ppm) and were significantly higher compared to those of sites 1,2,3, and 7.Average TP and TN concentrations for site 2 were 0.59 and $3.34 \mathrm{mg} \mathrm{L}^{-1}$ (0.59 and $\left.3.34 \mathrm{ppm}\right)$, respec- tively. Average DO concentration for site 7 was $3.44 \mathrm{mg} \mathrm{L}^{-1}$. The lower level of DO concentration in site 7 is due to the cumulative effects of oxygen-demanding substances on DO levels at the lower reaches of the watershed and the relatively slower moving water downstream. Differences in TSS and nutrient concentrations at the seven monitoring locations are closely associated with land use types and agricultural practices. For example, the drainage areas for sites 4, 5, and 6 consisted of primarily rice/crawfish systems followed by soybean production, and that of sites 2 largely consisted of pasture lands followed by rice/ crawfish and soybeans. Other researchers have 
Table 7

Spatial differences in surface water quality in Bayou Plaquemine Brule Watershed, Louisiana, from 2002 to 2008 . Values of all water characteristic parameters (five-day biological oxygen demand [ $\mathrm{BOD}_{5}$ ], total suspended solids [TSS], nitrate/nitrite-nitrogen [ $\left.\mathrm{NO}_{3} / \mathrm{NO}_{2}-\mathrm{N}\right]$, total nitrogen [TN], soluble reactive phosphate [SRP], total phosphorus [TP], temperature, conductivity, pH, turbidity, and dissolved oxygen [DO]) are calculated independently of seasons and regular and rain event samplings.

\begin{tabular}{|c|c|c|c|c|c|c|c|}
\hline Parameter & Site 1 & Site 2 & Site 3 & Site 4 & Site 5 & Site 6 & Site 7 \\
\hline \multicolumn{8}{|c|}{$\mathrm{BOD}_{5}\left(\mathrm{mg} \mathrm{L}^{-1}\right)$} \\
\hline$n$ & 138 & 140 & 136 & 139 & 139 & 139 & 139 \\
\hline Mean & $4.21( \pm 0.28) b$ & $4.91( \pm 0.26) a b$ & $4.58( \pm 0.28) a b$ & $4.35( \pm 0.22) b$ & $5.54( \pm 0.34) a$ & $4.71( \pm 0.27) a b$ & $5.07( \pm 0.31) a b$ \\
\hline Range & $0.10-25.35$ & 0.70 to 15.60 & 0.82 to 16.95 & 0.51 to 19.00 & 1.00 to 19.00 & 1.00 to 25.00 & 0.10 to 29.00 \\
\hline Median & 3.42 & 4.00 & 4.00 & 4.00 & 4.00 & 4.00 & 4.00 \\
\hline \multicolumn{8}{|c|}{ TSS (mg L-1) } \\
\hline $\mathrm{n}$ & 141 & 142 & 139 & 142 & 142 & 142 & 141 \\
\hline Mean & $80.33( \pm 6.90) b$ & $80.55( \pm 8.39) b$ & $67.86( \pm 8.35) b$ & $119.38( \pm 9.87) a$ & $140.25( \pm 17.04) \mathrm{a}$ & $118.41( \pm 12.95) \mathrm{a}$ & $58.58( \pm 5.83) b$ \\
\hline Range & 0.10 to 522.00 & 0.10 to 727.00 & 0.10 to 704.00 & 2.40 to 809.00 & 2.83 to 1730.00 & 0.10 to 910.00 & 0.10 to 419.00 \\
\hline Median & 53.48 & 56.51 & 35.00 & 84.00 & 92.65 & 75.50 & 36.32 \\
\hline \multicolumn{8}{|c|}{$\mathrm{NO}_{3} / \mathrm{NO}_{2}-\mathrm{N}\left(\mathrm{mg} \mathrm{L}^{-1}\right)$} \\
\hline $\mathrm{n}$ & 140 & 140 & 137 & 140 & 140 & 140 & 140 \\
\hline Mean & $1.07( \pm 0.09) \mathrm{ns}$ & $1.37( \pm 0.10) \mathrm{ns}$ & $1.28( \pm 0.15) \mathrm{ns}$ & $1.27( \pm 0.08) \mathrm{ns}$ & $1.16( \pm 0.09) \mathrm{ns}$ & $1.25( \pm 0.09) \mathrm{ns}$ & $1.13( \pm 0.08) \mathrm{ns}$ \\
\hline Range & 0.10 to 10.57 & 0.10 to 11.13 & 0.09 to 14.15 & 0.07 to 5.91 & 0.07 to 6.27 & 0.09 to 7.96 & 0.04 to 7.24 \\
\hline Median & 0.89 & 1.20 & 1.00 & 1.20 & 0.90 & 1.10 & 1.00 \\
\hline \multicolumn{8}{|l|}{$\mathrm{TN}\left(\mathrm{mg} \mathrm{L}^{-1}\right)$} \\
\hline $\mathrm{n}$ & 128 & 128 & 125 & 128 & 128 & 128 & 128 \\
\hline Mean & $2.74( \pm 0.12) \mathrm{b}$ & $3.34( \pm 0.14) a$ & $2.89( \pm 0.15) a b$ & $2.86( \pm 0.11) a b$ & $3.16( \pm 0.17) a b$ & $3.21( \pm 0.16) a b$ & $2.74( \pm 0.10) b$ \\
\hline Range & 0.20 to 6.94 & 0.70 to 10.10 & 0.78 to 12.10 & 0.80 to 8.98 & 1.10 to 13.60 & 0.87 to 14.60 & 1.03 to 1.98 \\
\hline Median & 2.40 & 3.01 & 2.30 & 2.70 & 2.60 & 2.90 & 2.50 \\
\hline \multicolumn{8}{|c|}{$\operatorname{SRP}\left(\mathrm{mg} \mathrm{L}^{-1}\right)$} \\
\hline $\mathrm{n}$ & 131 & 131 & 128 & 131 & 131 & 131 & 131 \\
\hline Mean & $0.29( \pm 0.01) b$ & $0.45( \pm 0.04) \mathrm{a}$ & $0.31( \pm 0.02) b$ & $0.25( \pm 0.01) b c$ & $0.25( \pm 0.02) b c$ & $0.22( \pm 0.01) c$ & $0.24( \pm 0.01) b c$ \\
\hline Range & 0.02 to 0.86 & 0.10 to 3.75 & 0.03 to 1.08 & 0.03 to 0.80 & 0.03 to 2.06 & 0.01 to 0.63 & 0.06 to 0.54 \\
\hline Median & 0.27 & 0.37 & 0.27 & 0.23 & 0.19 & 0.21 & 0.23 \\
\hline \multicolumn{8}{|l|}{$\mathrm{TP}\left(\mathrm{mg} \mathrm{L}^{-1}\right)$} \\
\hline $\mathrm{n}$ & 128 & 128 & 125 & 128 & 128 & 128 & 128 \\
\hline Mean & $0.42( \pm 0.02) b$ & $0.59( \pm 0.05) \mathrm{a}$ & $0.40( \pm 0.02) b$ & $0.37( \pm 0.01) \mathrm{b}$ & $0.37( \pm 0.03) b$ & $0.33( \pm 0.01) \mathrm{b}$ & $0.35( \pm 0.01) b$ \\
\hline Range & 0.08 to 1.35 & 0.15 to 4.25 & 0.09 to 1.20 & 0.08 to 0.88 & 0.05 to 2.50 & 0.08 to 0.83 & 0.10 to 0.82 \\
\hline Median & 0.37 & 0.50 & 0.37 & 0.34 & 0.30 & 0.29 & 0.34 \\
\hline \multicolumn{8}{|c|}{ Temperature $\left({ }^{\circ} \mathrm{C}\right)$} \\
\hline n & 143 & 143 & 140 & 143 & 141 & 143 & 138 \\
\hline Mean & $20.02( \pm 0.56) \mathrm{ns}$ & $20.5( \pm 0.6) \mathrm{ns}$ & $20.1( \pm 0.6) \mathrm{ns}$ & $20.9( \pm 0.5) \mathrm{ns}$ & $20.3( \pm 0.5) \mathrm{ns}$ & $20.4( \pm 0.5) \mathrm{ns}$ & $20.5( \pm 0.5) \mathrm{ns}$ \\
\hline Range & 4.40 to 33.11 & 5.09 to 31.44 & 5.22 to 34.56 & 7.55 to 30.58 & 4.57 to 30.51 & 7.14 to 31.15 & 9.26 to 29.54 \\
\hline Median & 20.62 & 21.06 & 20.88 & 21.89 & 21.21 & 21.77 & 21.11 \\
\hline \multicolumn{8}{|c|}{ Conductivity $\left(\mathrm{mS} \mathrm{cm}^{-1}\right)$} \\
\hline $\mathrm{n}$ & 143 & 143 & 140 & 143 & 141 & 143 & 137 \\
\hline Mean & $0.48( \pm 0.03) \mathrm{cd}$ & $0.53( \pm 0.03) c$ & $0.49( \pm 0.02) \mathrm{cd}$ & $0.49( \pm 0.03) \mathrm{cd}$ & $0.75( \pm 0.04) \mathrm{a}$ & $0.61( \pm 0.03) \mathrm{b}$ & $0.41( \pm 0.03) d$ \\
\hline Range & 0.04 to 1.61 & 0.04 to 1.42 & 0.01 to 1.81 & 0.05 to 1.28 & 0.11 to 1.75 & 0.08 to 1.81 & 0.07 to 1.49 \\
\hline Median & 0.41 & 0.46 & 0.41 & 0.42 & 0.65 & 0.55 & 0.31 \\
\hline \multicolumn{8}{|l|}{$\mathrm{pH}$} \\
\hline$n$ & 137 & 138 & 135 & 138 & 136 & 138 & 133 \\
\hline Mean & $7.57( \pm 0.05) a b$ & $7.53( \pm 0.04) a b$ & $7.47( \pm 0.04) b$ & $7.63( \pm 0.04) \mathrm{a}$ & $7.63( \pm 0.03) \mathrm{a}$ & $7.66( \pm 0.03) \mathrm{a}$ & $7.67( \pm 0.04) a$ \\
\hline Range & 5.79 to 8.96 & 5.97 to 8.74 & 6.11 to 8.59 & 6.12 to 9.00 & 6.18 to 9.04 & 5.76 to 8.83 & 5.67 to 9.12 \\
\hline Median & 7.63 & 7.62 & 7.60 & 7.66 & 7.67 & 7.72 & 7.70 \\
\hline \multicolumn{8}{|c|}{ Turbidity (NTU) } \\
\hline $\mathrm{n}$ & 143 & 143 & 140 & 143 & 141 & 143 & 138 \\
\hline Mean & $138.9( \pm 14.9) b$ & $144.1( \pm 16.9) \mathrm{b}$ & 133.1( \pm 17.9$) \mathrm{b}$ & $218.0( \pm 28.4) \mathrm{ab}$ & $257.7( \pm 39.1) a$ & 263.1( \pm 38.9$) \mathrm{a}$ & $208.7( \pm 26.2) \mathrm{ab}$ \\
\hline Range & 2.20 to 1286.70 & 9.30 to 1637.03 & 4.73 to 1682.30 & 21.00 to 2891.57 & 4.05 to 4633.90 & 6.57 to 3632.70 & 3.40 to 2573.40 \\
\hline Median & 76.57 & 72.40 & 58.02 & 125.60 & 146.60 & 115.00 & 116.71 \\
\hline \multicolumn{8}{|l|}{$\mathrm{DO}\left(\mathrm{mg} \mathrm{L}^{-1}\right)$} \\
\hline$n$ & 143 & 143 & 139 & 142 & 140 & 142 & 137 \\
\hline Mean & $6.91( \pm 0.20) \mathrm{a}$ & $6.22( \pm 0.21) \mathrm{abc}$ & $6.60( \pm 0.21) \mathrm{ab}$ & $5.63( \pm 0.19) c$ & $5.59( \pm 0.23) c$ & $6.15( \pm 0.21) b c$ & $3.44( \pm 0.19) d$ \\
\hline Range & 0.47 to 12.97 & 0.44 to 12.51 & 0.56 to 12.31 & 0.63 to 11.10 & 1.04 to 12.21 & 0.59 to 12.16 & 0.43 to 10.36 \\
\hline Median & 6.54 & 5.90 & 6.23 & 5.12 & 5.24 & 5.80 & 2.73 \\
\hline
\end{tabular}

Notes: $\mathrm{n}=$ sample size. $\mathrm{ns}=$ not significant. Numbers given in parentheses are the standard error of mean. Values across the row with different letters are significantly different at 0.05 probability level by Student-Newman-Keuls test. 


\section{Table 8}

Correlation coefficients for dissolved oxygen (DO), turbidity (turb.), conductivity (cond.), temperature (temp.), pH, total suspended solids (TSS), fiveday biological oxygen demand ( $\mathrm{BOD}$ ), total nitrogen ( $T N$ ), nitrate/nitrite-nitrogen ( $\mathrm{NO}_{3} / \mathrm{NO}_{2}-\mathrm{N}$ ), total phosphorus (TP), soluble reactive phosphorus (SRP), total combustible solids (TCS), and total Kjeldahl nitrogen (TKN), in Bayou Plaquemine Brule Watershed, 2002 to 2008.

\begin{tabular}{|c|c|c|c|c|c|c|c|c|c|c|c|c|c|}
\hline & DO & Turb. & Cond. & Temp. & pH & TSS & BOD $_{5}$ & TN & $\mathrm{NO}_{3} / \mathrm{NO}_{2}-\mathrm{N}$ & TP & SRP & TCS & TKN \\
\hline DO & 1 & & & & & & & & & & & & \\
\hline \multirow[t]{2}{*}{ Turb. } & $0.08 *$ & 1 & & & & & & & & & & & \\
\hline & $(n=986)$ & & & & & & & & & & & & \\
\hline \multirow[t]{2}{*}{ Cond. } & $-0.17 * * *$ & $-0.08 *$ & 1 & & & & & & & & & & \\
\hline & $(n=985)$ & $(n=990)$ & & & & & & & & & & & \\
\hline \multirow[t]{2}{*}{ Temp. } & $-0.70 * * *$ & $-0.02 \mathrm{~ns}$ & $0.14 * * *$ & 1 & & & & & & & & & \\
\hline & $(n=986$ & $(n=991)$ & $(n=990)$ & & & & & & & & & & \\
\hline \multirow[t]{2}{*}{$\mathrm{pH}$} & $0.04 \mathrm{~ns}$ & $-0.09 * *$ & $0.12 * * *$ & $0.05 n s$ & 1 & & & & & & & & \\
\hline & $(n=958)$ & $(n=955)$ & $(n=954)$ & $(n=955)$ & & & & & & & & & \\
\hline \multirow[t]{2}{*}{ TSS } & $0.07 *$ & $0.59 * * *$ & $-0.05 n s$ & $0.03 n s$ & $-0.02 n s$ & 1 & & & & & & & \\
\hline & $(n=970)$ & $(n=975)$ & $(n=974)$ & $(n=975)$ & $(n=939)$ & & & & & & & & \\
\hline \multirow[t]{2}{*}{$\mathrm{BOD}_{5}$} & $-0.25 * * *$ & $0.17 * * *$ & $0.22 * * *$ & $0.24 * * *$ & $-0.03 n s$ & $0.29 * * *$ & 1 & & & & & & \\
\hline & $(n=951)$ & $(n=956)$ & $(n=955)$ & $(n=956)$ & $(n=925)$ & $(n=970)$ & & & & & & & \\
\hline \multirow[t]{2}{*}{ TN } & $-0.22 * * *$ & $0.25 * * *$ & $0.17 * * *$ & $0.24 * * *$ & $-0.01 n s$ & $0.30 * * *$ & $0.43 * * *$ & 1 & & & & & \\
\hline & $(n=875)$ & $(n=880)$ & $(n=879)$ & $(n=880)$ & $(n=851)$ & $(n=893)$ & $(n=879)$ & & & & & & \\
\hline \multirow[t]{2}{*}{$\mathrm{NO}_{3} / \mathrm{NO}_{2}-\mathrm{N}$} & -0.05 ns & $0.14 * * *$ & $0.23 * * *$ & $0.22 * * *$ & $0.01 \mathrm{~ns}$ & $0.07 *$ & $0.26 * * *$ & $0.39 * * *$ & 1 & & & & \\
\hline & $(n=958)$ & $(n=963)$ & $(n=962)$ & $(n=963)$ & $(n=927)$ & $(n=968)$ & $(n=949)$ & $(n=893)$ & & & & & \\
\hline \multirow[t]{2}{*}{$\mathrm{TP}$} & $-0.17 * * *$ & $-0.04 n s$ & $-0.01 n s$ & $0.16 * * *$ & $-0.03 n s$ & $0.07 n s$ & $0.25 * * *$ & $0.25 * * *$ & $0.13 * * *$ & 1 & & & \\
\hline & $(n=875)$ & $(n=880)$ & $(n=879)$ & $(n=880)$ & $(n=851)$ & $(n=893)$ & $(n=879)$ & $(n=893)$ & $(n=893)$ & & & & \\
\hline \multirow[t]{2}{*}{ SRP } & $-0.17 * * *$ & $-0.10 * *$ & $0.02 \mathrm{~ns}$ & $0.15 * * *$ & $-0.001 n s$ & $-0.03 n s$ & $0.18 * * *$ & $0.21 * * *$ & $0.16 * * *$ & $0.87 * * *$ & 1 & & \\
\hline & $(n=895)$ & $(n=900)$ & $(n=899)$ & $(n=900)$ & $(n=864)$ & $(n=914)$ & $(n=895)$ & $(n=893)$ & $(n=914)$ & $(n=893)$ & & & \\
\hline \multirow[t]{2}{*}{ TCS } & $0.06 \mathrm{~ns}$ & $0.63 * * *$ & $-0.15 * *$ & $-0.12 *$ & $0.01 \mathrm{~ns}$ & $0.83 * * *$ & $0.22 * * *$ & $0.29 * * *$ & $0.04 n s$ & $0.26 * * *$ & $0.05 n s$ & 1 & \\
\hline & $(n=319)$ & $(n=324)$ & $(n=324)$ & $(n=324)$ & $(n=317)$ & $(n=327)$ & $(n=322)$ & $(n=231)$ & $(n=306)$ & $(n=231)$ & $(n=252)$ & & \\
\hline \multirow[t]{2}{*}{ TKN } & $-0.16 * * *$ & $0.18 * * *$ & $0.09 *$ & $0.17 * * *$ & $-0.01 n s$ & $0.24 * * *$ & $0.27 * * *$ & $0.88 * * *$ & $-0.12 * * *$ & $0.18 * * *$ & $0.11 * *$ & $0.17 *$ & 1 \\
\hline & $(n=814)$ & $(n=81)$ & $(n=818)$ & $(\mathrm{n}=819)$ & $(n=790)$ & $(n=830)$ & $(n=816)$ & $(n=830)$ & $(n=830)$ & $(n=830)$ & $(n=829)$ & $(n=168)$ & \\
\hline
\end{tabular}

Note: $\mathrm{ns}=$ not significant at 0.05 probability level.

$* p<.05 * * p<.01 * * * p<.001$

also reported associations between surface water quality and land use types and agricultural practices. Poudel et al. (2010) reported higher TSS concentration in surface runoff from sugarcane fields compared to that of pasture lands and residential areas and higher TP and SRP concentrations in surface runoff from pasturelands compared to sugarcane fields and residential areas in the VermilionTeche River Basin in Louisiana. Similarly, James et al. (2007) reported significant amounts of $\mathrm{P}$ deposition directly into streams by pastured dairy cattle with stream access in Cannonsville Watershed in New York.

Relationship between Surface Water Quality Parameters. Total suspended solids were significantly correlated with turbidity, $\mathrm{BOD}_{5}, \mathrm{TN}, \mathrm{TKN}, \mathrm{TCS}$, and nonsignificantly correlated with TP and SRP (table 8). Similar results of significant correlation between TSS and $\mathrm{TN}, \mathrm{NO}_{3} / \mathrm{NO}_{2}-\mathrm{N}$, and $\mathrm{BOD}_{5}$ and nonsignificant correlation of TSS and TP and SRP are reported by Poudel et al. (2010) for a nearby watershed in Louisiana. These results indicate that the TSS in this region is associated largely with $\mathrm{N}$ and oxygen-demanding substances. In addition, high and significant correlation between TP and SRP suggest the presence of readily available $\mathrm{P}$ for uptake by aquatic plants, including algae, in the water body, risking algal bloom and water quality impairment.

While DO was significantly negatively correlated with water temperature $(r=-0.70$, $p \leq 0.001)$, it was slightly but significantly negatively correlated with conductivity $(r=$ $-0.17 p \leq 0.001), \mathrm{BOD}_{5}(r=-0.25 p \leq 0.001)$, $\mathrm{TN}(r=-0.22, p \leq 0.001), \mathrm{TP}(r=-0.17, p \leq$ $0.001), \operatorname{SRP}(r=-0.17, p \leq 0.001)$, and TKN $(r=-0.16, p \leq 0.001)$ (table 8). The best relationship between the DO levels and stream water temperature was established with the second order polynomial regression in this study (figure 9). The second order polynomial regression of untransformed data gave better fit compared to any of the square root, natural $\log$, and inverse transformations as well as the simple linear regression. Equation
1 below shows relationship between DO $\left(\mathrm{mg} \mathrm{L}^{-1}\right)$ and surface water temperature $\left({ }^{\circ} \mathrm{C}\right)$ for the pooled dataset $\left(r^{2}=0.53, p \leq 0.001\right)$ :

$\mathrm{DO}=10.62-0.26$ (temperature) +0.01 (temperature -20.39$)^{2}$

Higher water temperatures result in lower levels of DO due to a decreased solubility of $\mathrm{O}_{2}$ in the water. Influence of water temperature on DO levels in water are also reported by other researchers (Laurie 1942; Hanson et al. 2006). In our study, the stream water temperature ranged between $4.4^{\circ} \mathrm{C}$ to $34.6^{\circ} \mathrm{C}$ $\left(39.9^{\circ} \mathrm{F}\right.$ to $\left.94.2^{\circ} \mathrm{F}\right)$. Average monthly stream temperature in summer was as high as $27.7^{\circ} \mathrm{C}$ $\left(81.9^{\circ} \mathrm{F}\right)$. These high water temperatures apparently cause a decline in DO levels in the summer months in Bayou Plaquemine Brule. In a forest system, greater diurnal variation of stream temperatures are reported in those streams where clear-cut harvesting rather than patch-cutting was practiced (Lynch et al. 1984). Clearance of streamside 
vegetation affects the stream temperature, which in turn alters the balance of net radiation, turbulent heat exchange across the water surface boundary, and stream/streambed heat exchange (Sridhar et al. 2004). As changes in stream temperatures affect the biochemical processes in the water, the DO and aquatic life in a water body are also affected. Tate et al. (2005) have reported a diurnal pattern of DO levels in a stream in California; they noted higher DO levels in midafternoon to late afternoon due to $\mathrm{O}_{2}$ production by aquatic plants and lower DO levels before dawn due to the plant's nighttime respiration. As all the sampling sites were lacking sufficient shade from streamside vegetation, DO could have been affected considerably due to increased stream temperatures in Bayou Plaquemine Brule Watershed.

Factors Associated with Surface Water Quality Variability. Table 9 shows principal components and factors associated with surface water quality variability in Bayou Plaquemine Brule Watershed as a result of our statistical analysis. Since there was some improvement on the cumulative proportion of the variability explained by principal components using transformed data compared to untransformed data, principal component results from square root transformed data are reported. Sediment, P, N, surface water temperature, dissolved solids, and acidity/ alkalinity were identified as the major factors associated with surface water quality variability in Bayou Plaquemine Brule Watershed. However, the seasonal analyses showed $\mathrm{N}$ as factor 2 and $\mathrm{P}$ as factor 3 for the summer and $\mathrm{P}$ as factor 2 and $\mathrm{N}$ as factor 3 for the winter. It is important to consider these factors when designing and implementing appropriate best management practices (BMPs) in order to improve and maintain surface water quality in this watershed. As sediments, $\mathrm{P}$, and $\mathrm{N}$ were the three major factors associated with surface water quality variability in this watershed (table 9), it is essential to identify critical areas for nonpoint source pollution of sediment, $\mathrm{P}$, and $\mathrm{N}$ and implement conservation measures for effective nonpoint source pollution control in the Bayou Plaquemine Brule Watershed.

Critical Areas for Nonpoint Source Pollution of Sediment, Phosphorus, and Nitrogen. The SWAT simulation results showed higher sediment loads for subbasins 7 and 4 and higher TN and TP loads for subba$\sin 7$ (figure 10), suggesting higher nonpoint

\section{Figure 9}

Polynomial regression between dissolved oxygen (DO, $\left.\mathrm{mg} \mathrm{L}^{-1}\right)$ levels and the stream water temperatures $\left({ }^{\circ} \mathrm{C}\right)$ in Bayou Plaquemine Brule Watershed, Louisiana (2002 to 2008).

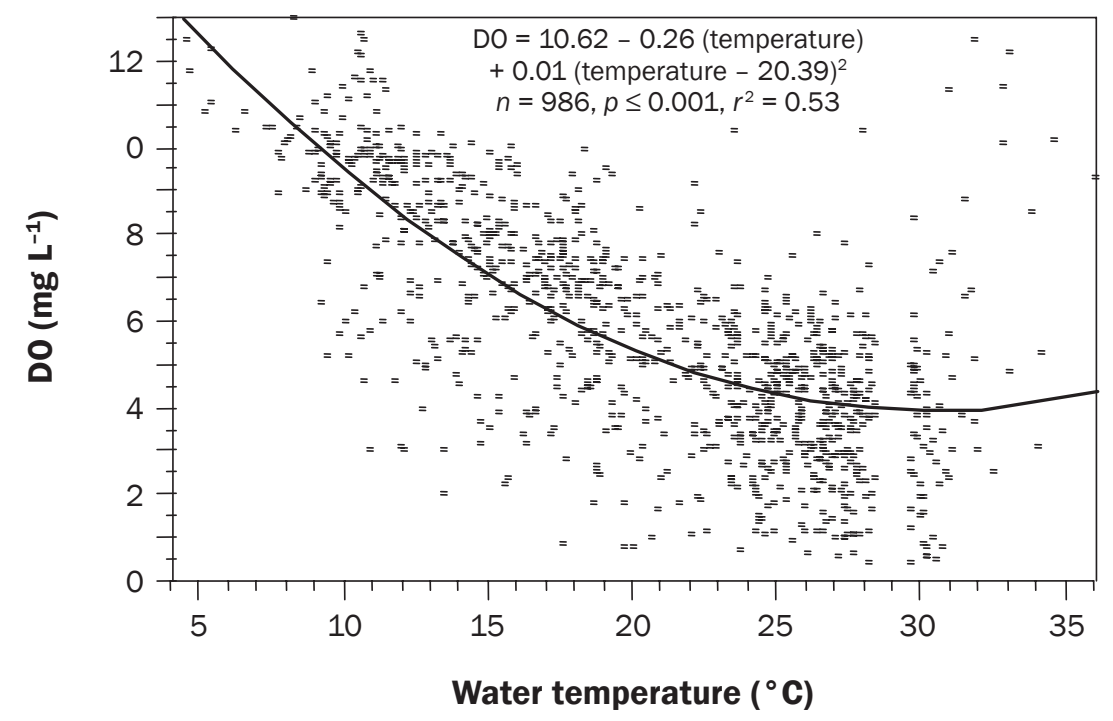

source pollution on the lower reaches of the watershed. The different land use types/land cover between the upper reaches and the lower reaches of the watershed have resulted in the different pollution loads. While the upper reaches of the watershed largely consisted of pasture lands, sugarcane, rice/ crawfish, and soybean production, the lower reaches of the watershed consisted primarily of rice/crawfish and soybean production. Also, since the implementation of BMPs in agricultural lands during project duration were concentrated in the upper reaches of the watershed, especially subbasins 5 and 3, the BMPs might have contributed to the reduction of nonpoint source pollution loads in the upper reaches of the watershed. Other researchers have also reported similar differences in land use types, seasonal agricultural activities, and inputs use for the variations of nonpoint source pollutant loadings in agricultural watersheds (Owens et al. 1991; Carpenter et al. 1998; Brett et al. 2005).

Critical areas for nonpoint source pollution of sediments, $\mathrm{P}$, and $\mathrm{N}$ identified by the SWAT model contrasted with the concentration data generated from monitoring. While subbasin 1 with an average $80.33 \mathrm{mg}$ $\mathrm{L}^{-1}$ (80.33 ppm) TSS concentration at site 1 was identified as the low sediment load subbasin, subbasin 7 with an average TSS concentration of $58.58 \mathrm{mg} \mathrm{L}^{-1}$ (58.58 ppm) at site 7 was identified as the high sediment load subbasin. Similar results were obtained with respect to $\mathrm{TP}$ and $\mathrm{TN}$. These results clearly indicate that a lower in-stream concentration of a pollutant at the lower reaches of the watershed does not necessarily mean the land areas nearby the lower reaches of the watershed are less polluting or vice versa. The reduced concentration of TSS, TN, and $\mathrm{TP}$ in the lower reaches of the watershed is apparently due to the hydrological differences of the Bayou Plaquemine Brule between its upper reaches and the lower reaches. In the lower reaches, the Bayou contains a huge amount of water, and the water moves very slowly. The Bayou Plaquemine Brule at site 7 consistently had a large amount of algal growth during this study. The slow movement of the Bayou at the lower reaches of the watershed has resulted in the settlement of sediments, breakdown of $\mathrm{N}$, the consumption of $\mathrm{NO}_{3}$ and SRP by algae, and the lower in-stream concentration of TSS, $\mathrm{TN}$, and TP even though nonpoint source pollution critical areas for sediment, $\mathrm{P}$, and $\mathrm{N}$ were identified in the lower researches of the watershed.

\section{Summary and Conclusions}

Seasonal and spatial variation in surface water quality exists in Bayou Plaquemine Brule Watershed. While significantly higher concentrations of TSS, BOD, TN, TKN, $\mathrm{NO}_{3} / \mathrm{NO}_{2}-\mathrm{N}, \mathrm{SRP}$, and TP were found in the summer season, significantly higher concentration of DO was observed in winter. Also, water quality parameters following rain events showed significant differences, espe- 


\section{Table 9}

Number of principal components, variances (i.e., eigenvalues), cumulative proportion of variability, and the water quality parameters (five-day biological oxygen demand $\left[\mathrm{BOD}_{5}\right.$ ], total suspended solids [TSS], nitrate/nitrite-nitrogen $\left[\mathrm{NO}_{3} / \mathrm{NO}_{2}-\mathrm{N}\right]$, total nitrogen [TN], soluble reactive phosphate [SRP], total phosphorus [TP], temperature, conductivity, $\mathrm{pH}$, turbidity, total combustible solids (TCS), total Kjeldahl nitrogen [TKN], and dissolved oxygen [DO]) having higher loadings on the varimax rotated factors for the summer and the winter seasons and the whole year with square root transformation of water quality data in Bayou Plaquemine Brule Watershed, Louisiana, from March of 2002 to February of 2008.

\begin{tabular}{|c|c|c|c|c|}
\hline $\begin{array}{l}\text { Principal } \\
\text { Component } \\
\text { (Yi ) }\end{array}$ & $\begin{array}{l}\text { Eigenvalue } \\
\text { (גi) }\end{array}$ & $\begin{array}{l}\text { Cumulative } \\
\text { proportion of } \\
\text { variability }\end{array}$ & $\begin{array}{l}\text { Parameters with higher } \\
\text { loadings on the } \\
\text { rotated factors }\end{array}$ & Factor identified \\
\hline \multicolumn{5}{|l|}{ Summer } \\
\hline$Y_{2}$ & 2.27 & 42.81 & TKN, TN & Nitrogen \\
\hline$Y_{3}$ & 1.61 & 55.18 & TP, SRP & Phosphorus \\
\hline$Y_{6}$ & 1.03 & 82.18 & $\mathrm{pH}$ & Acidity/alkalinity \\
\hline \multicolumn{5}{|l|}{ Winter } \\
\hline$Y_{1}$ & 3.32 & 25.54 & TCS, TSS, turbidity & Sediment \\
\hline$Y_{2}$ & 2.29 & 43.21 & SRP, TP & Phosphorus \\
\hline$Y_{3}$ & 2.01 & 58.66 & $\mathrm{TKN}, \mathrm{NO}_{3} / \mathrm{NO}_{2}-\mathrm{N}, \mathrm{TN}$ & Nitrogen \\
\hline$Y_{2}$ & 2.43 & 45.26 & SRP, TP & Phosphorus \\
\hline$Y_{3}$ & 1.60 & 57.57 & TKN, TN & Nitrogen \\
\hline $\mathrm{Y}_{4}$ & 1.34 & 67.84 & Temperature, DO & Temperature \\
\hline$Y_{5}$ & 1.11 & 76.41 & $\mathrm{NO}_{3} / \mathrm{NO}_{2}-\mathrm{N}$, conductivity & Dissolved solids \\
\hline$Y_{6}$ & 1.00 & 84.14 & $\mathrm{pH}$ & Acidity/alkalinity \\
\hline
\end{tabular}

\section{Figure 10}

Nonpoint source pollution critical areas based on annual sediment and nutrient loads for (a) sediment, (b) total phosphorus (TP), and (c) total nitrogen (TN) in Bayou Plaquemine Brule Watershed, Louisiana. Overall, the annual loads estimated by the model indicated that subbasins 4 and 7 (sampling sites 4 and 7) generated highest loadings in the watershed. For sediment, subbasins 4 and 7 were included in the highest loading category, for which annual average sediment load was more than $5 \mathrm{t} \mathrm{ha}^{-1}$. Only subbasin 7 showed as a high load subbasin for TN (over $6 \mathrm{~kg}$ ha ${ }^{-1}$ ) as well as for TP (over $3 \mathrm{~kg} \mathrm{ha}^{-1}$ ).

\section{(a) Sediment load}

Low (under $1 \mathrm{t} \mathrm{ha}^{-1}$ )
Medium
High (over $5 \mathrm{t} \mathrm{ha}^{-1}$ )

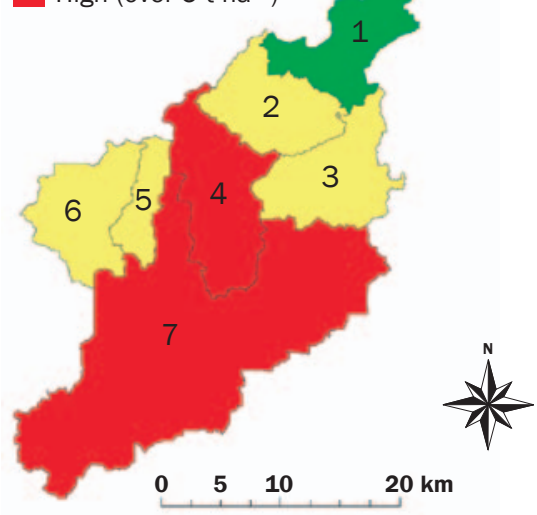

\section{(b) TP load}

Low (under $1 \mathrm{~kg} \mathrm{ha}{ }^{-1}$ )
Medium
High (over $3 \mathrm{~kg} \mathrm{ha}^{-1}$ )

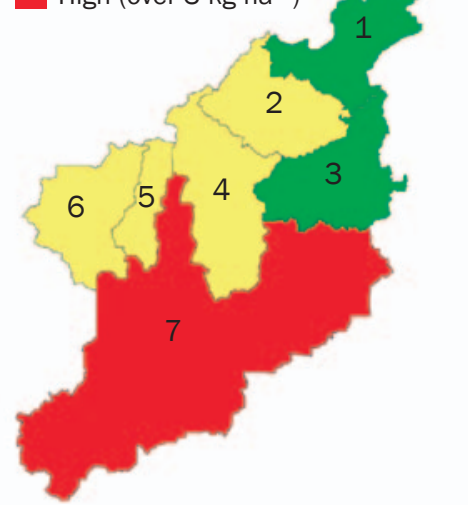

(c) TN load
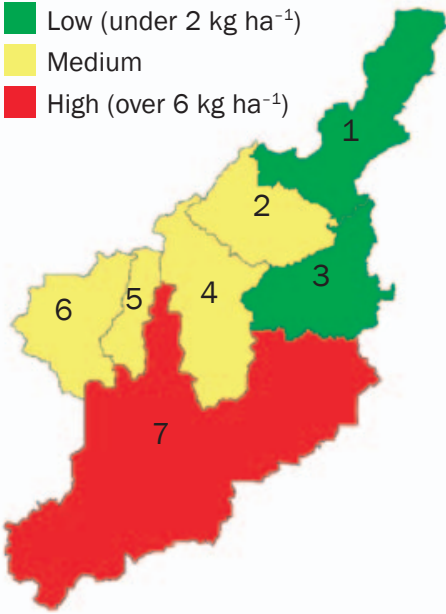
cially on TSS, SRP, TP, and DO for both the summer and the winter seasons, suggesting that special attention should be given in controlling nonpoint source pollution in this watershed. Several water quality parameters were strongly correlated. Total suspended solids and TCS were significantly moderately correlated with turbidity, while TSS was strongly significantly correlated with TCS. Similarly, there were strong and significant correlations between TP and SRP and TN and TKN. These correlations suggest that only one of the two correlates will give sufficient information for nonpoint source pollution in this watershed; hence, one of them may be dropped from monitoring list and save time, labor, and laboratory costs. Factors associated with the surface water quality variability included the suspended solids, P, N, water temperature, dissolved solids, and acidity/alkalinity. The variability in surface water quality explained by these factors was in the order of sediment $>\mathrm{P}>\mathrm{N}>$ water temperature $>$ dissolved solids $>$ acidity/alkalinity. Sufficient considerations should be given to these factors while implementing conservation measures for effective nonpoint source pollution control in this watershed. In addition, the presence of the critical areas for nonpoint source pollution of sediments and nutrients in the lower reaches of the watershed suggests the need for implementation of conservation measures in the lower reaches for nonpoint source pollution control in this watershed. The integrated approach of monitoring and modeling of the surface water quality resulted in a valuable information on the seasonal and spatial variability of surface water quality, factors associated with water quality variability, and the critical areas for nonpoint source pollution in the Bayou Plaquemine Brule Watershed. This information can be effectively utilized in sound decision making for nonpoint source pollution control and water quality improvement in the watershed.

\section{Acknowledgements}

We acknowledge the Environmental Protection Agency Region VI and the Louisiana Department of Environmental Quality for 319 Grant funding for this study. We also acknowledge the continuous assistance provided by Jack Haller with the Natural Resources Conservation Service in Crowley, Louisiana. We thank many Louisiana Department of Environmental Quality professionals including Jan Boydstun, John James Clark, Max Forbes, Steve Kolian, Ross Hartfield, Kurt Johnson, Cortez Rankin, Regie Coleman, and many others who have helped us in implementing this project. We are grateful to University of Louisiana-Lafayette faculty, staff, and students who assisted us in this project. We would like to thank the two anonymous reviewers of the manuscript who provided us invaluable suggestions, comments, and high-quality reviews.

\section{References}

Abbaspour, K.C., C.A. Johnson, and M.Th. van Genuchten. 2004. Estimating uncertain flow and transport parameters using a Sequential Uncertainty Fitting procedure.Vadose Zone Journal 3:1340-1352.

Abbaspour, K.C., J.Yang, I. Maximov, R. Siber, K. Bogner, J. Mieleitner, J. Zobrist, and R. Srinivasan. 2007. Modelling hydrology and water quality in the pre-alpine/alpine Thur watershed using SWAT. Journal of Hydrology 333:413-430.

Alkarkhi, A.F.M., A. Ahmad, N. Ismail, A. mat Easa, and K. Omar. 2008. Assessment of surface water through multivariate analysis. Journal of Sustainable Development 1(3):27-33.

Arnold, J.G., R. Srinivasan, R.S. Muttiah, and J.R. Williams. 1998. Large area hydrologic modeling and assessment. Part I. Model development. Journal of the American Water Resources Association 34(1):73-89.

Bennett, H.H., M.W. Mullen, P.M. Stewart, J.A. Sawyer, and E.C. Webber. 2004. Development of an invertebrate community index for an Alabama coastal plain watershed. Journal of the American Water Resources Association 40(1):43-51.

Berger, Jr., W.C., J. Carney, and R.K. Duerr. 2000. Bayou Plaquemine Brule watershed TMDL to address dissolved oxygen and nutrients including eight point source wasteload allocations and a watershed nonpoint source load allocation, Subsegment 0502, Volume I, TMDL Report Appendix A-D, Water Quality Modeling Section. Baton Rouge, LA: Watershed Support Division, Office of Water Resources, Louisiana Department of Environmental Quality.

Bouraoui, F., and T.A. Dillaha. 2000. ANSWERS-2000: Nonpoint source nutrient planning model. Journal of Environmental Engineering 126(11):1045-1055.

Brett, M.T., G.B. Arhonditsis, S.E. Mueller, D.M. Hartley, J.D. Frodge, and D.E. Funke. 2005. Non-point-source impacts on stream nutrient concentrations along a forest to urban gradient. Environmental Management 35(3):330-342.

Busteed, P.R., D.E. Storm, M.J. White, and S.H. Stoodley. 2009. Using SWAT to target critical source sediment and phosphorus areas in the Wister Lake Basin, USA. American Journal of Environmental Sciences 5(2):156-163.

Carpenter, S.R., N.F. Caraco, D.L. Correll, R.W. Howarth, A.N. Sharpley, and V.H. Smith. 1998. Nonpoint pollution of surface waters with phosphorus and nitrogen. Ecological Applications 8:559-568.
Clarke, R.A., C.D. Stanley, B.L. McNeal, and B.W. MacLeod. 2002. Impact of agricultural land use on nitrate levels in Lake Manatee, Florida. Journal of Soil and Water Conservation 57(2):106-111.

Clesceri, L.S., A.E. Greenberg, and A.D. Eaton, eds. 1998. Standard Methods for the Examination of Water and Wastewater, 20th ed. Washington, DC: American Public Health Association

Davenport, T.E., D.W. Meals, and S.A. Dressing. 2008. Monitoring, modeling and decision making: Making it work. National Water Quality Monitoring Council Sixth National Monitoring Conference, Atlantic City, New Jersey, May 18-22, 2008. Alexandria, VA: Water Environment Federation. http://acwi.gov/monitoring/ conference/2008/papers/I2-D.pdf.

Demcheck, D.K., R.W. Tollett, S.V. Mize, S.C. Skrobialowski, R.B. Fendick Jr., C.M. Swarzenski, and S.D. Porter. 2004. Water quality in the AcadianPontchartrain drainages, Louisiana and Mississippi, 1999-2001. US Geological Survey Circular 1232.

El-Kaddah, D.N., and A.E. Carey. 2004. Water quality modeling of the Cahaba River, Alabama. Environmental Geology 45:323-338.

Eyles, R., D. Niyogi, C. Townsend, G. Benwell, and P. Weinstein. 2003. Spatial and temporal patterns of Campylobacter contamination underlying public health risk in Taieri River, New Zealand. Journal of Environmental Quality 32:1820-1828.

Forster, D.L., R.R. Richards, D.B. Baker, and E.N. Blue. 2000. EPIC modeling of the effects of farming practice changes on water quality in two Lake Erie watersheds. Journal of Soil and Water Conservation 55(1):85-90.

France-Lanord, C., M. Evans, J. Hurtrez, and J. Riotte. 2003. Annual dissolved fluxes from central Nepal rivers: Budget of chemical erosion in the Himalayas. C.R. Geosciences 335:1131-1140.

Gelbrecht, J., H. Lengsfeld, R. Pöthig, and D. Opitz. 2005. Temporal and spatial variation of phosphorus input, retention and loss in a small catchment of NE Germany. Journal of Hydrology 304:151-165.

Geza, M., and J.E. McCray. 2008. Effects of soil data resolution on SWAT model stream flow and water quality predictions. Journal of Environmental Management 88:393-406

Hamilton, P.A., and T.L. Miller. 2002. Lessons from the national water-quality assessment. Journal of Soil and Water Conservation 57(1):16A- 21A.

Hanson, P.C., S.R. Carpenter, D.E. Armstrong, E.H. Stanley, and T.K. Kratz. 2006. Lake dissolved inorganic carbon and dissolved oxygen: Changing drivers from days to decades. Ecological Monographs 76(3):343-363.

Hongbing, L., L. Lin, H. Gu, L. Ping, L. Jingxian, H. Sheng, W. Fuxiang, X. Rui, and H. Xiaoxue. 2009. Total pollution effect of urban surface runoff. Journal of Environmental Sciences 21(9):1186-1193.

James, E., P. Kleinman, T. Veith, R. Stedman, and A. Sharpley. 2007. Phosphorus contributions from pastured dairy 
cattle to streams of the Cannonsville Watershed, New York. Journal of Soil and Water Conservation 62(1):40-47. Jaynes, D.B., D.L. Dinnes, D.W. Meek, D.L. Karlen, C.A. Cambardella, and T.S. Colvin. 2004. Using the late spring nitrate test to reduce nitrate loss within a watershed. Journal of Environmental Quality 33:669-677.

Jha, M., P.W. Gasssman, S. Secchi, R. Gu, and J. Arnold. 2004. Effect of watershed subdivision on SWAT flow, sediment, and nutrient predictions. Journal of the American Water Resources Association 40(3):811-825.

Laurie, E.M.O. 1942. The dissolved oxygen of an upland pond and its inflowing stream at Ystumtuen, North Cardiganshire, Wales. Journal of Ecology 30(2):357-382

LDEQ (Louisiana Department of Environmental Quality) 1999. Bayou Plaquemine Brule watershed TMDL to address dissolved oxygen and nutrients including eight point source wasteload allocations and a watershed nonpoint source load allocation. Subsegment 0502 Volume 1. Baton Rouge, LA:TMDL Report, Louisiana Department of Environmental Quality.

LIDAR. 2012. Atlas: The Louisiana Statewide GIS. Baton Rouge, LA: Louisiana State University CADGIS Research Laboratory. http://atlas.lsu.edu.

Lynch, J.A., G.B. Rishel, and E.S. Corbett. 1984 Thermal alteration of stream draining clear-cut watersheds: Quantification and biological implications. Hydrobiologia 111:161-169.

Mankin, K.R., S.H. Wang, J.K. Koelliker, D.G. Huggins, and F. deNoyelles. 2003. Watershed-lake water quality modeling: Verification and application. Journal of Soil and Water Conservation 58(4):188-197.

Mazlum, N., A. özer, and S. Mazlum. 1999. Interpretation of water quality data by principal components analysis. Turkish Journal of Engineering and Environmental Sciences 23:19-26.

Nagano, T., N. Yanase, K. Tsuduki, and S. Nagao. 2003. Particulate and dissolved elemental loads in the Kuji River related to discharge rate. Environment International 28:649-658.

Owens, L.B., W.M. Edwards, and R.W. Van Keuren. 1991 Baseflow and stormflow transport of nutrients from mixed agricultural watersheds. Journal of Environmental Quality 20:407-414.

Poudel, D.D. 2006. Challenges for improving surface water quality in an agricultural watershed in Louisiana. In Coastal Environment and Water Quality, Proceedings of the AIH 25th Anniversary Meeting \& International Conference, Challenges in Coastal Hydrology and Water Quality, Water Resources Publications, Highlands Ranch, CO, eds. Y.J. Xu and V.P. Singh, 251-261.

Poudel, D.D., and C.Y. Jeong. 2009. Manual composite sampling in edge-of-field surface runoff for assessing nonpoint source pollution from agricultural lands and residential areas. Journal of Soil and Water Conservation 64(5):324-335.
Poudel, D.D., C.Y. Jeong, and A. DeRamus. 2010 Surface run-off water quality from agricultural lands and residential areas. Outlook on Agriculture 39(2):95-105.

Poudel, D.D., and M.J. Simon. 2008. Pasture-based dairy and water hyacinth (Eichornia crassipes) for reduced biological oxygen demand in dairy discharge water. Outlook on Agriculture 37(2):135-142.

Praus, P. 2007. Urban water quality evaluation using multivariate analysis. Acta Montanistica Slovaca 12(2):150-158.

Radcliffe, D.E., Z. Lin, L.M. Risse, J.J. Romeis, and C.R. Jackson. 2009. Modeling phosphorus in the Lake Allatoona watershed using SWAT: I. Developing phosphorus parameters values. Journal of Environmental Quality 38:111-120.

Randall, G.W., J.A. Vetsch, and J.R. Huffman. 2003. Nitrate loss in subsurface drainage from a corn-soybean rotation as affected by time of nitrogen application and use of Nitrapyrin. Journal of Environmental Quality 32:1764-1772.

Romanowicz, A.A., M. Vanclooster, M. Rounsevell, and I. La Junesse. 2005. Sensitivity of the SWAT model to the soil and land use data paramterisation: A case study in the Thyle catchment, Belgium. Ecological Modeling 187:27-39.

Rostamian, R., A. Jaleh, M. Afyuni, S.F. Mousavi, M. Heidarpour, A. Jalalian, and K.C. Abbaspour. 2008. Application of a SWAT model for estimating runoff and sediment in two mountainous basins in central Iran. Hydrological Sciences 53(5):977-988.

SAS (Statistical Analysis Systems). 2003. The Statistical Analysis System Software for Windows. SAS 9.1.3 (9.1 TS1M3 2002-2003). Cary, NC: SAS Institute Inc.

Sridhar, V., A.L. Sansone, J. LaMarche, T. Dublin, and D. Lettenmair. 2004. Prediction of stream temperature in forested watersheds. Journal of the American Water Resources Association 40(1):197-213

Srinivasan, M.S., P. Gérard-Marchant, T.L. Veith, W.J Gburek, and T.S. Steenhuis. 2005. Watershed scale modeling of critical source areas of runoff generation and phosphorus transport. Journal of the American Water Resources Association 41(2):361-375

Tate, K.W., D.F. Lile, D.L. Lancaster, M.L. Porath, J.A. Morrison, and Y. Sado. 2005. Graphical analysis facilities evaluation of stream-temperature monitoring data. California Agriculture 59(3):153-160.

USDA NRCS (Natural Resources Conservation Service). 2012. Soil Data Mart. Washington, DC: USDA Natural Resources Conservation Service. http://soildatamart. nrcs.usda.gov/USDGSM.aspx.

USGAO (US General Accounting Office). 1990. Water pollution: Greater EPA leadership needed to reduce nonpoint source pollution. RCED-91.10. Gaithersburg, MD: US Government Accounting Office. http://www. gao.gov/assets/150/149860.pdf.
USGS (US Geological Survey). 2012. Instantaneous Data Archive. Reston, VA: US Geological Survey. http://ida. water.usgs.gov/ida/.

Wang, Y., Z. Lou, C. Sun, M. Wu, and S. Han. 2006. Multivariate statistical analysis of water quality and phytoplankton characteristics in Daya Bay, China, from 1999 to 2002. Oceanologia 48(2):193-211.

Winter, T.C. 2007. The role of ground water in generating streamflow in headwater areas and in maintaining base flow. Journal of the American Water Resources Association. 43(1):15-25. 